\title{
Using monazite and zircon petrochronology to constrain the P-T-t evolution of the middle crust in the Bhutan Himalaya
}

\author{
D. Regisa, C. J. Warrena, C. M. Mottrama,b, N. M. W. Robertsc \\ a Department of Environment, Earth and Ecosystems, The Open University, Walton Hall, Milton \\ Keynes MK7 6AA, UK \\ (daniele.regis@canada.ca) \\ ${ }^{\mathrm{b}}$ Department of Earth Sciences, Dalhousie University, Halifax, NS B3H 4R2, Canada \\ ' NERC Isotope Geosciences Laboratory, British Geological Survey, Kingsley Dunham Centre, \\ Keyworth NG12 5GG, UK
}

\section{Abstract}

The growth and dissolution behaviour of accessory phases (and especially those of geochronological interest) in metamorphosed pelites depends on, among others, the bulk composition, the prograde metamorphic evolution and the cooling path. Monazite and zircon are arguably the most commonly used geochronometers for dating felsic metamorphic rocks, yet crystal growth mechanisms as a function of rock composition, pressure and temperature are still incompletely understood. Ages of different growth zones in zircon and monazite in a garnet-bearing anatectic metapelite from the Greater Himalayan Sequence in NW Bhutan were investigated via a combination of thermodynamic modelling, microtextural data and interpretation of trace-element chemical 'fingerprint' indicators in order to link them to the metamorphic stage at which they crystallized. Differences in the traceelement composition (HREE, $\mathrm{Y}, \mathrm{Eu}_{\mathrm{N}} / \mathrm{Eu}^{*}{ }_{\mathrm{N}}$ ) of different phases were used to track the growth/dissolution of major (e.g. plagioclase, garnet) and accessory phases (e.g. monazite, zircon, xenotime, allanite). Taken together, these data constrain multiple pressure-temperature-time $(P-T-$ $t$ ) points from low temperature $\left(<550^{\circ} \mathrm{C}\right)$ to upper amphibolite facies (partial melting, $>700{ }^{\circ} \mathrm{C}$ ) conditions. The results suggest that the metapelite experienced a cryptic early metamorphic stage at c. $38 \mathrm{Ma}$ at $<550{ }^{\circ} \mathrm{C}, \geq 0.85 \mathrm{GPa}$ during which plagioclase was probably absent. This was followed by a prolonged high- $T$, medium-pressure $\left(\sim 600^{\circ} \mathrm{C}, 0.55 \mathrm{GPa}\right)$ evolution at 35-29 Ma during which the garnet grew, and subsequent partial melting at $>690^{\circ} \mathrm{C}$ and $>18 \mathrm{Ma}$. Our data confirm that both geochronometers can crystallize independently at different times along the same $P-T$ path and that neither monazite nor zircon necessarily provides timing constraints on 'peak' metamorphism. Therefore, collecting monazite and zircon ages as well as major and trace-element data from major and accessory phases in the same sample is essential for reconstructing the most coherent metamorphic $P-T-t$ evolution and thus for robustly constraining the rates and timescales of metamorphic cycles. 


\section{Introduction}

Determination of the rates and timescales of tectonic processes that bury and exhume crustal rocks depends on knowledge of: (i) absolute time, measured by radioactive decay, and (ii) the $P-$ $T$ conditions to which those times relate. Radioisotope ratios in accessory minerals such as monazite, zircon, rutile and titanite commonly yield the most precise information about time, whereas the major element compositions of rock-forming minerals are most commonly used for calculating $P-$ $T$ estimates. There has been recent concerted effort into linking 'age' to 'stage' using trace elements as reaction 'fingerprints' (e.g. Möller et al., 2003; Rubatto et al., 2006, 2013; Dumond et al., 2015; Holder et al., 2015).

Monazite and zircon $\mathrm{U}-\mathrm{Th}-\mathrm{Pb}$ ages underpin a wide variety of tectonic interpretations and reconstructions, especially those involving processes in the middle and lower continental crust. However, in order to give weight to these interpretations, and determine rates of change, monazite and zircon 'dates' need to be tied to geological 'events' within the host rock $P-T$ evolution. Of particular importance is the determination of whether these accessory minerals formed during prograde metamorphism, during melting at or around peak temperature, or during the retrograde overprint at supra- or sub-solidus conditions. This is particularly relevant for monazite, which, during regional metamorphism of metapelites, can readily crystallize under sub-solidus conditions (e.g. Rubatto et al., 2001; Wing et al., 2003) and can either crystallize or dissolve in the presence of melt (e.g. Kelsey et al.,2008; Stepanov et al., 2012; Yakymchuk \& Brown, 2014).

Despite the huge amount of $\mathrm{U}-\mathrm{Th}-\mathrm{Pb}$ and/or chemical data from monazite and zircon published in the last few decades, few studies report data from both minerals in the same rock sample (e.g. Aleinikoffet al., 2000; Buick et al., 2006; Rubatto et al., 2006, 2013; Bhowmik et al., 2014; Hallett \& Spear, 2015; Zeiger et al., 2015). The collection of data from both monazite and zircon from the same sample rather than from different rock types of the same geological terrane can reduce the uncertainty about bulk composition effects (e.g. Kelsey et al., 2008), although it does not entirely avoid the effects of, for example, bulk fractionation or melt extraction. The interpretation of any age difference between co-hosted monazite and zircon is furthermore complicated by age dispersion (analytical or geological), poly-metamorphism and/or partial resetting of ages (e.g. Aleinikoff et al., 2000; Rubatto et al., 2001, 2006, 2013; Zeh et al., 2003; Bhowmik et al., 2014; Gasser et al., 2015; Hallett \& Spear, 2015; Zeigeret al., 2015). However, monazite and zircon provide complimentary data sets that can reveal information about the prograde, peak and retrograde metamorphic history. Pre-existing zircon tends to remain relatively unreactive during amphibolite facies metamorphism, and new zircon overgrowths tend to only occur at very fine spatial scales (e.g. Harrison \& Watson, 1983; Rubatto et al., 2001; Cottleet al., 2009; Gordon et al., 2009). Zircon rims commonly only provide a record of a single growth event during a metamorphic cycle, and generally, but not always, only grow in the presence of melt (e.g. Tomkins et al., 2005; Rubatto et al., 2006). Monazite, however, commonly reacts multiple times during a metamorphic cycle, preserving evidence for multiple episodes of growth, dissolution and re-growth; these episodes are possibly identifiable by differing trace-element concentrations, especially in $\mathrm{Y}$ and Th (e.g.

Kohn et al., 2004, 2005). These chemical variations have been used to link the timing of episodes of monazite growth to the petrological evolution of the host rock (e.g. Foster et al., 2002, 2004; Pyle \& Spear, 2003; Gibson et al., 2004; Kelly et al., 2006, 2012; Yang \& Pattison, 2006; Majkaet al., 2012; Catlos, 2013; Larson et al., 2013; Rubatto et al., 2013; Bhowmik et al., 2014; Mottramet al., 2015). 
Despite the clear advantages of monazite as a metamorphic chronometer, research into monaziteforming reactions, and the links between monazite crystallization and the evolution of the host rock, has lagged behind those related to zircon. Several studies have demonstrated qualitative links between monazite growth and the evolution of the host rock, by way of microstructural proxy methods such as the association of monazite in micro-structural domains, for example, symplectites (e.g. Kelsey et al., 2003) or the inclusion of monazite in host minerals such as garnet or kyanite (e.g. Foster et al., 2004; Martin et al., 2007; Mottram et al., 2014). Quantitative geochemical proxy methods, using trace-element concentrations and the evolution of the trace-element compositions within accessory phases and among major rock-forming minerals are, however, being developed, particularly for use in thermobarometry (e.g. Gratz \& Heinrich, 1997; Heinrich et al., 1997; Pyle \& Spear, 2000; Pyle et al., 2001; Ferry \& Watson, 2007).

Recent research has focused on using accessory phase data derived from both experiment and natural examples and incorporated into thermodynamic databases to formulate new activitycomposition relationships for accessory phases. For example, recent advances involve investigating systematic changes in $\mathrm{Zr}$ across different $P-T$ conditions (to model zircon) and LREE (to model monazite), (Kelseyet al., 2008; Kelsey \& Powell, 2011; Stepanov et al., 2012; Yakymchuk \& Brown, 2014). These investigations have provided preliminary predictions on the growth and dissolution behaviour of monazite and zircon as a function of pressure, temperature and rock composition. Testing these predictions on natural samples is now key.

The evolution of major and accessory phase trace-element concentrations have been largely used to link the growth and dissolution of monazite to the metamorphic evolution of the sample. One of the most widely used approaches involves the recognition that $Y$ and Th zoning in monazite form in response to different metamorphic reactions (e.g. Spear \& Pyle, 2002; Pyle \& Spear, 2003; Kohn \& Malloy, 2004; Kohn et al., 2004, 2005). Due to the competition between garnet and monazite for $Y$, the $Y$ content of monazite is linkable to prograde and retrograde reactions involving garnet (e.g. Pyle et al.,2001; Pyle \& Spear, 2003; Kohn et al., 2004, 2005; Tobgay et al., 2012). Monazite growing in the presence of garnet incorporates relatively low $Y$ concentrations; monazite growing in the absence of garnet, or during garnet breakdown, incorporates higher $Y$ concentrations. During partial melting, monazite is considered to readily dissolve, and garnet considered to continue crystallizing. Cooling during retrogression, melt crystallization and garnet breakdown is thought to trigger the growth of high-Y monazite, either as new grains or as overgrowths on older monazite cores (e.g. Pyle \& Spear, 2003; Kohn et al., 2004, 2005). High-Y monazite cores have therefore traditionally been interpreted as forming before garnet (early prograde growth), lower $Y$ (inner) rims as forming in the presence of garnet (prograde-to-peak, immediately pre-melting) and high-Y outer rims as forming during or post-melt crystallization (e.g. Kohn et al., 2004, 2005; Tobgay et al., 2012).

This interpretation, however, is only strictly valid in a system where monazite and garnet (or monazite, garnet and melt) are the only $\mathrm{Y}$ - and REE-bearing phases co-reacting at that particular time. In more complex systems, in which several accessory phases (e.g. zircon, xenotime, allanite, apatite) may be involved in the metamorphic evolution, the simple interpretation as outlined above may not be correct, as the availability of, and competition for, different trace elements will vary at different times during the metamorphic evolution (e.g. Pyle \& Spear, 2003). 
Here, we present the results of a detailed petrological study of a Greater Himalayan Sequence (GHS) metapelite sample DRB1250, collected in NW Bhutan, eastern Himalaya. In this sample, several 'chemical fingerprints' have been used together with petrological and geochronological data to constrain the growth/dissolution of zircon and monazite along a reconstructed $P-T$ path from subsolidus lower amphibolite facies conditions through peak supra-solidus upper-amphibolite facies conditions and back into the sub-solidus during retrogression. This study aims to assess the validity of the simple interpretation that low-Y monazite cores are always relatable to the last stages of prograde metamorphism and that high-Y monazite rims are always associated with decompression and cooling. Our approach is multi-faceted, combining microtextural evidence with: (i) petrological analysis of the metamorphic rock sample to determine the sequence of mineral growth, (ii) quantification of the physical and chemical conditions of the rock evolution, and (iii) age dating of suitable geochronometers that are linked via microstructural observations or chemistry to identified stages in the rock evolution. In detail, our data show that the patterns of trace elements incorporated by zircon and monazite during growth and dissolution are related and relatable to the growth and dissolution of other phases in the rock, but not always in the simple manner suggested by previous studies. Overall, our data show that detailed microstructural and petrographic evolution observations, combined with detailed trace-element chemistry, dating and $P-T$ modelling greatly aid in the interpretation of the tectono-metamorphic evolution of the sample in detail and of the geological terrane of interest in general.

\section{Geological setting}

The Himalayan orogen is the lithospheric expression of the ongoing continental collision between India and Asia. After initial collision in the early Paleogene (estimates ranging from 60 to $50 \mathrm{Ma}$, for example, Leech et al., 2005; Zhu et al., 2005; DeCelles et al., 2014; Hu et al., 2015), the Eocene to late Oligocene was characterized by crustal thickening and Barrovian metamorphism of the Indian continental margin under Tibet, followed by partial melting in the middle crust (e.g. Simpson et al., 2000; Kellett et al., 2010; 2014; Smit et al., 2014). This highly metamorphosed material was subsequently extruded southwards during the Miocene, although the exact mechanism by which this was achieved is still debated (e.g. Grujic et al., 2002; Searle et al., 2003, 2006; Jamieson et al., 2004, 2006; Webb et al., 2007, 2011; Kohn, 2008; Corrie et al., 2012; Leger et al., 2013; Cottle et al., 2015; Larson et al., 2015).

The Himalayan orogen bedrock is divided into four orogen-parallel tectonostratigraphic zones, bounded by major normal and thrust-sense structures (Heim \& Gansser, 1939; Gansser, 1964, 1983; Powell \& Conaghan, 1973; Seeber \& Armbruster, 1981). From south to north (structurally low to high), these units and structures include (Fig. 1a): the Main Frontal Thrust, the sub-Himalayan thrust system and Siwalik belt, the Main Boundary Thrust, the Lesser Himalayan Sequence, the Main Central Thrust (MCT), the GHS, the South Tibetan Detachment System (STD), and the Tethyan Sedimentary Sequence.

Much of the country of Bhutan, in the eastern Himalaya, is dominated by exposures of amphiboliteto granulite facies GHS rocks (Fig. 1a,b), which crop out over a north-south orogenic width of 60 $100 \mathrm{~km}$ between the STD and the MCT. In Bhutan the STD comprises two main structures: the 'inner', brittle-ductile STD that separates high- $T$ metamorphic rocks of the GHS from low metamorphic grade Tethyan sedimentary rocks along the northern border between Bhutan and 
Tibet, and the 'outer', ductile, STD that juxtaposes high-grade GHS rocks against metamorphosed Tethyan sedimentary rocks, the Chekha Formation (metapelite/calcsilicate), in the western and central parts of Bhutan (Fig. 1a,b; Kellett et al., 2009). The GHS in Bhutan comprises paragneiss, orthogneiss, quartzite, leucogranite, and less commonly, marble and garnet-amphibolite layers (e.g. Gansser, 1983). Within the GHS, paragneiss and quartzite become more common up-section, as do migmatite and leucogranite produced by dehydration and partial melting reactions (Davidson et al., 1997; Grujicet al., 2002; Daniel et al., 2003). Along the Paro Chu valley (Fig. 1 $\mathrm{b}$ ) coarse-grained anatectic metapelites ( $\mathrm{Bt}+\mathrm{Grt}+\mathrm{Sil}+\mathrm{PI}+\mathrm{Qz} \pm \mathrm{Kfs}$ ) occur close ( $2 \mathrm{~km})$ to the 'outer' STD contact. The pelitic rocks are commonly associated with augen-gneiss and small ( $\sim 10 \mathrm{~cm}$ thick) leucogranitic dykes (Fig. 2a).

\section{Methods}

\section{Major element chemistry and imaging}

Back-scattered electron images and electron-microprobe analyses on major phases were performed on polished thin sections at the Open University with a Cameca SX100 (5 spectrometer) Electron Microprobe (EMP). Operating conditions were set to $15 \mathrm{kV}$ and $20 \mathrm{nA}$ (spot size $\sim 1 \mu \mathrm{m}$ ) for major phases and $25 \mathrm{kV}$ and $50 \mathrm{nA}$ (spot size $3 \mu \mathrm{m}$ ) for the REE-bearing minerals. A ZAF matrix correction routine was used. A selection of natural standards was used for calibration and unknowns were bracketed by analyses of internal secondary standards to check running conditions. Uncertainty on major element concentrations is $<1 \%$. X-ray elemental maps were obtained for $\mathrm{Ce}, \mathrm{Y}, \mathrm{P}, \mathrm{U}$ and $\mathrm{Th}$ in monazite and for $\mathrm{Ca}, \mathrm{Fe}, \mathrm{Mg}$ and $\mathrm{Mn}$ in garnet, using the EMP with a beam set at $15 \mathrm{kV}$ and $20 \mathrm{nA}$. Step size was $0.5 \mu \mathrm{m}$ and dwell time per pixel was $20-40 \mathrm{~ms}$.

Chemical formulae were calculated stoichiometrically based on 12 oxygen for garnet, 8 for plagioclase and K-feldspar and 22 for biotite (Tables 1 \& S1). Bulk-rock composition of sample DRB1250 was acquired from mapping of three thin sections $(2 \times 4 \mathrm{~cm})$, using the CAMECA SX100 electron microprobe at The Open University. The thin sections were scanned in a mosaic mode $(4 \times 7$ grid) with operating conditions of $20 \mathrm{kV}$ and $20 \mathrm{nA}$. Dwell time was set at $5 \mathrm{~ms}$ with a step size of $20 \mu \mathrm{m}$; qualitative maps were obtained for $\mathrm{Na}, \mathrm{K}, \mathrm{Fe}, \mathrm{Ca}$ and $\mathrm{Al}$. To get a precise point-counted estimation of mineral proportions, the qualitative maps were processed using ImageJ 1.46r software (http://imagej.nih.gov/ij).

Cathodoluminescence $(\mathrm{CL})$ imaging of zircon grains was carried out on a FEI Quanta 600 ESEM scanning electron microscope (SEM) fitted with an ellipsoidal mirror for $\mathrm{CL}$ at the British Geological Survey, Keyworth. Operating conditions for the SEM were $10 \mathrm{nA}$ and $15 \mathrm{~mm}$ working distance.

\section{Trace-element acquisition}

Trace-element compositions of garnet, zircon and monazite grains were analysed on an Agilent 7500 s quadrupole inductively coupled plasma mass spectrometer coupled to a New Wave $213 \mathrm{~nm}$ $\mathrm{Nd}$-YAG laser ablation system at the Open University, Milton Keynes. Laser beam diameters were $20 \mu \mathrm{m}$ for monazite and zircon, and $40 \mu \mathrm{m}$ for garnet, with an energy density on the sample of $7 \mathrm{~J} \mathrm{~cm}^{-2}$. A He-Ar gas mixture was used as the aerosol transport gas. During the analyses, each set of 8-10 unknown ablation spots was bracketed with NIST SRM 610 glass measurements (for monazite 
and zircon) and 612 glass measurements (for garnet). Variations in standard intensity were interpolated between successive standard measurements and corrected using internal standards (Ca for garnet and Ce for monazite - EMP analyses, stoichiometric Si for zircon). Data reduction was performed using Glitter software (Macquarie University, Australia). Accuracy was monitored using NIST SRM 610 and NIST SRM 612 for garnet and monazite/zircon, respectively, which yielded mean values within uncertainty of reference values (Horn et al., 1997; Pearce et al., 1997). All the data were normalized according to the chondrite values of McDonough \& Sun (1995).

\section{$\mathrm{U}-(\mathrm{Th})-\mathrm{Pb}$ monazite and zircon geochronology}

In situ monazite and zircon $\mathrm{U}-\mathrm{Th}-\mathrm{Pb}$ geochronology were performed to provide insight into the duration and timing of the metamorphic cycle. Monazite grains were chosen based on size and chemistry. Only monazite grains $>50 \mu \mathrm{m}$ diameter were chosen due to laser spot size constraints (15 $\mu \mathrm{m}$ minimum). Prior to analysis, grains were mapped for $\mathrm{U}, \mathrm{Th}, \mathrm{Y}$ and $\mathrm{Ce}$ to identify elemental zoning, assist laser spot location and facilitate age interpretation.

$\mathrm{U}-\mathrm{Th}-\mathrm{Pb}$ analysis was performed using a New Wave Research UP193 Nd:YAG laser ablation system coupled to an AttoM single-collector ICP-MS at the NERC Isotope Geosciences Laboratory (NIGL) Geochronology and Tracers Facility, UK. A spot size of $15 \mu \mathrm{m}$ was used for monazite, with a laser fluence of $\sim 2.2 \mathrm{~J} \mathrm{~cm}^{-2}$. U-Th-Pb data were normalized to monazite reference material 'Stern' [primary, $512.1 \pm 1.9 \mathrm{Ma}(2 \mathrm{SD}), \mathrm{ID}-\mathrm{TIMS}{ }^{238} \mathrm{U}{ }^{206} \mathrm{~Pb}$ average age, Palin et al., 2013], and secondary reference materials 'Manangotry' [559 $\pm 1 \mathrm{Ma}(2 \mathrm{SD})$, ID-TIMS ${ }^{238} \mathrm{U}-{ }^{206} \mathrm{~Pb}$ average age, Palin et al., 2013] and 'Moacyr' [515.6 $\pm 1.4 \mathrm{Ma}(2 \mathrm{SD})$, ID-TIMS ${ }^{238} \mathrm{U}-{ }^{206} \mathrm{~Pb}$ average age, Palin et al., 2013] were analysed to check precision and accuracy. The precision achieved on the reference materials was $2-3 \%$ (2SD) for $\mathrm{U}-\mathrm{Pb}$ and 3-4\% (2SD) for Th-Pb data. All quoted uncertainties include contributions from the excess variance of the reference material for ${ }^{206} \mathrm{~Pb} /{ }^{238} \mathrm{U}$, and ${ }^{208} \mathrm{~Pb} /{ }^{232} \mathrm{Th}$ ratios. Data processing and reduction were undertaken using in-house spreadsheets at NIGL; Tera-Wasserburg diagrams and regression of corrected data were produced using Isoplot version 3.16 September 2008 (Ludwig, 2003). Analyses were corrected for common lead using either a linear regression indicated by the data, or, where less clear, regressed through a value of $0.83 \pm 0.02$ (based on Stacey \& Kramers, 1975). Final age uncertainties are quoted as $\pm x / y(2 \sigma)$, where $x$ includes the analytical and session-based uncertainties, and $y$ includes systematic uncertainties (decay constants, reference material uncertainty, long-term laboratory reproducibility). The analytical protocol, and young age of the samples (giving low ${ }^{208} \mathrm{~Pb}$ counts), means that the $\mathrm{Th}-\mathrm{Pb}$ ages have a greater uncertainty than the equivalent $\mathrm{U}-\mathrm{Pb}$ ages. For monazite, $\mathrm{Th}-\mathrm{Pb}$ ages are often preferred, as there is no issue with excess ${ }^{206} \mathrm{~Pb}$. Here, we present $\mathrm{U}-\mathrm{Pb}$ ages that are corrected for excess ${ }^{206} \mathrm{~Pb}$ using a whole-rock Th/U ratio of 3 , and note that the equivalent $\mathrm{Th}-\mathrm{Pb}$ ages are generally overlapping within uncertainty, and do not yield different results (see Fig. S3).

Zircon grains, clear to light yellow in colour and generally euhedral (50-150 $\mu \mathrm{m})$, were separated using conventional magnetic and density-based techniques, mounted in a $25 \mathrm{~mm}$ epoxy resin disc and polished to expose near-equatorial sections. Ablation parameters were $5 \mathrm{~Hz}$, with a fluence of $\sim 2.5 \mathrm{~J} \mathrm{~cm}^{-2}$, a $30 \mathrm{~s}$ ablation time, and a $20 \mu \mathrm{m}$ spot size (see Spencer et al., 2014 for a full description of the technique). Zircon reference materials (91500, GJ-1 and Plešovice) were analysed at regular intervals; and the standard sample bracketing routine involved normalization to the drift-corrected 
mean fractionation factor (measured/accepted $\mathrm{Pb}-\mathrm{U}$ ratio) for the three reference materials (91500, GJ-1, Plešovice). The precision of the ${ }^{206} \mathrm{~Pb} /{ }^{238} \mathrm{U}$ measurements of the reference materials was $3-4 \%$. All uncertainty ellipses plotted on the Tera-Wasserburg diagrams are at the $2 \sigma$ confidence level.

\section{Pressure-temperature modelling}

The pseudosection approach has been widely used to investigate the $P-T$ evolution of metapelites (e.g. Zeh, 2001; Tinkham \& Ghent, 2005; Gaidies et al., 2006; Caddick et al., 2007; Guilmette et al., 2011; Groppo et al., 2012; Sorcar et al., 2014; Mottram et al., 2015) as the pelitic system is very reactive to $P-T$ variations. The choice of the model system and the variations in the bulk composition due to fractionation as a result of the presence of zoned porphyroblasts (e.g. garnet) are important aspects that have to be considered. The NCKFMASH system is generally considered representative for metapelites (e.g. White et al., 2001) and $\mathrm{MnO}$ and $\mathrm{TiO}_{2}$ are often important additional components (e.g. White et al., 2000).

We have modelled DRB1250 in the MnNCKFMASTH system, as this is considered to be the most appropriate to model the phase development observed in the sample. The influence of $\mathrm{Fe}_{2} \mathrm{O}_{3}$ was ignored because epidote and magnetite are absent and the calculated amount of $\mathrm{Fe}^{3+}$ in the analysed phases (e.g. garnet) is negligible.

Pseudosections were calculated following the approach of Connolly (1990) (Perple_X version 6_6_8) using the internally consistent thermodynamic data set and equation of state for $\mathrm{H}_{2} \mathrm{O}$ of Holland \& Powell (1998, revised 2004). The following solid solution models were used: plagioclase

(Newton et al., 1980), K-feldspar (Thompson \& Hovis, 1979), biotite (Tajcmanová et al., 2009), white mica (Holland \& Powell, 1998), chloritoid (White et al., 2000), garnet (Holland \& Powell, 1998), chlorite (Holland et al., 1998), melt (Holland \& Powell, 2001; White et al., 2001), ilmenite (ideal) and cordierite (ideal). Additional pure phases considered in the pseudosections include quartz, aluminium silicates, zoisite, titanite and rutile. The white mica solid solution model of Holland \& Powell (1998) correctly predicts the stability field of K-rich white mica but currently does not correctly incorporate the amount of $\mathrm{Na}$ in the mica. The main consequence of this is the modelled appearance of paragonite (e.g. Groppo et al., 2009). In the modelled pseudosections the two mica types (muscovite and paragonite) are referred to as $2 \mathrm{Wm}$ when they are stable together.

Pownceby et al. (1987) demonstrated that $\mathrm{Mn}$ incorporation into ilmenite can be significant and the $\mathrm{Fe}-\mathrm{Mn}$ partitioning between ilmenite and garnet can play a significant role in the stability and composition of low- $T$ garnet. Therefore, $\mathrm{Mg}$ and $\mathrm{Mn}$ mixing were permitted in ilmenite rather than modelling it as pure $\mathrm{FeTiO}_{3} . \mathrm{H}_{2} \mathrm{O}$ was treated as a perfectly mobile component. Fluid was considered as pure $\mathrm{H}_{2} \mathrm{O}\left(\mathrm{aH}_{2} \mathrm{O}=1\right)$, which is a generally accepted approximation for pelitic systems (e.g. Groppo et al., 2009).

The studied metapelite contains zoned garnet crystals. Among the major elements, $\mathrm{MnO}$ is mainly sequestered in garnet cores, resulting in its possible chemical fractionation during prograde garnet growth. The pseudosection approach requires that the bulk composition of the rock is effectively in equilibrium during each stage of garnet growth, which is clearly not the case where garnet is zoned. The method of Evans (2004) was used to assess the importance of chemical fractionation as a result of garnet growth. This method applies a Rayleigh fractionation model based on the measured $\mathrm{Mn}$ content of garnet and requires the existence of a linear correlation between the concentration of $\mathrm{Mn}$ compared to $\mathrm{Fe}, \mathrm{Mg}$ and $\mathrm{Ca}$ in garnet. Two different equilibrium compositions were calculated: 
(i) the bulk composition corresponding to the equilibrium composition during garnet growth and (ii) the bulk-rock composition minus 3.1\% volume of the garnet core composition (estimated from the EMP thin section scans) which gives the equilibrium composition during the growth of the garnet rim. Two different pseudosections were calculated, one for each of the two bulk compositions.

\section{Results}

\section{Petrography and microtextures}

Sample DRB1250 was collected within the GHS in the Paro Chu valley (Fig. 1 b, $27^{\circ} 35^{\prime} 10.87^{\prime \prime} \mathrm{N}$ $\left.89^{\circ} 17^{\prime} 38.05^{\prime \prime} \mathrm{E}\right)$, in the footwall of the 'outer'-STD system. In hand-specimen the anatectic metapelite is characterized by a well-developed foliation ( $S_{m}$, Fig. 2a) marked by large flakes of biotite (>1 mm), white sillimanite and dark $\mathrm{mm}$-sized garnet porphyroblasts. The micaschist is associated with boudinaged leucogranitic dykes (d) parallel to the main foliation (Fig. 2a).

The sample comprises biotite (52\%), quartz (22\%), plagioclase (8\%), sillimanite (7\%), garnet (6\%), Kfeldspar (3\%), and accessory monazite, zircon, xenotime, allanite and ilmenite (2\%, Figs 2, 3 \& S1). The rock is dominated by mesocratic domains alternating with thin $(<1 \mathrm{~mm})$ discontinuous quartzofeldspathic leucocratic layers (Fig. 2b,d). No rutile or titanite was observed either in the matrix or as inclusions in garnet. In the mesocratic domains, garnet crystals are characterized by inclusion-rich cores $\left(\mathrm{Pl}_{1}+\mathrm{Qz}+\mathrm{Bt}_{1} \pm \mathrm{Xtm} \pm \mathrm{Zrn} \pm \mathrm{Aln} \pm \mathrm{llm}\right.$, Fig. $2 \mathrm{~g}$ ) and clear rims $( \pm \mathrm{Qz} \pm \mathrm{Zrn} \pm$ small $\mathrm{Mnz}$ ) that locally overgrow the foliation defined by biotite ${ }_{2}$ and sillimanite (Fig. $2 \mathrm{~b}-\mathrm{d}$ ); some garnet crystals show discontinuous plagioclase coronae.

Plagioclase ${ }_{2}$ and quartz crystals are abundant in the leucocratic domains, relative to K-feldspar. Alkali feldspar forms coarse-grained $\left(\leq 1 \mathrm{~mm}\right.$ ) poikiloblasts with inclusions of small blebby biotite $\left(\mathrm{Bt}_{2}\right)$, quartz and minor plagioclase and sillimanite (Fig. 2e,f). It is locally replaced at its rim by sillimanite (Fig. 2e). Other K-feldspar crystals are partially replaced by myrmekite structures (plagioclase with intergrowths of quartz, Fig. $\underline{2}$ f).

The sample preserves some microtextures related to melt-producing and melt-consuming reactions. The inclusions in K-feldspar suggest that it is a peritectic phase grown at the expense of biotite ${ }_{2}$, quartz, plagioclase and sillimanite (e.g. Sawyer, $\underline{\mathbf{2 0 0 8}}$ and references therein). Plagioclase and quartz myrmekitic structures replacing the same K-feldspar crystals in the leucocratic domains suggest that $\mathrm{K}$-feldspar was a reactant during the final stages of the metamorphic evolution. Other microtextures interpreted as related to back-reactions between solid phases and melt during final melt crystallization include fine-grained sillimanite aggregates replacing alkali feldspar at its rims, and discontinuous plagioclase coronae around garnet. No evidence for peritectic garnet growth (e.g. lobate inclusions of quartz) was observed.

In rare retrogressed portions of the sample, garnet shows breakdown textures to chlorite along cracks while biotite and sillimanite aggregates are partially replaced by muscovite (Fig. S1).

On the basis of these observations, the assemblage $\mathrm{Bt}_{1-2}+\mathrm{Grt}+\mathrm{Sil}+\mathrm{Pl}_{1-2}+\mathrm{Qz}$ is interpreted as growing during the prograde evolution, while the peak assemblage is characterized by the presence of melt and crystallization of poikilitic K-feldspar. The presence of microstructures indicating crystallization of trapped melt (e.g. back-reaction textures) suggests that the liquid was probably 
partially or completely preserved in the melting sites. The complete sequence of mineral growth is shown in Fig. $\underline{3}$.

\section{Mineral chemistry of major phases}

Garnet porphyroblasts preserve major element zonation (Fig. $\underline{4 a}$; Tables $\underline{1} \& \mathrm{~S} 1$ ). $X_{\mathrm{Grs}}$ and $X_{\mathrm{Sps}}$ show bell-shaped profiles that decrease from core to $\operatorname{rim}\left(X_{\mathrm{Grs}}\right.$ from 0.06 to $0.03, X_{\mathrm{Sps}}$ from 0.07 to 0.05 , Table S1). $X_{\text {Alm }}$ and $X_{\text {Pyp }}$ generally increase towards the rim ( $X_{\text {Alm }}$ from 0.69 to $0.74, X_{\text {Pyp }}$ from 0.14 to 0.15 , Table S1) with a slight $X_{\text {Pyp }}$ decrease towards the outermost rim (Fig. $\underline{4 a}$ ); the decrease in $\mathrm{Mg}$ corresponds to an increase in $X_{\text {sps. }}$. The transition between the inclusion-rich core and inclusion-poor rim is marked by a decrease in $X_{\text {Grs }}$ and $Y$ (Table 1 ; Fig. 4). Garnet crystals show chemical and microtextural evidence of resorption such as truncated major element zoning and $\mathrm{Mn}$-enriched rims (Fig. 4).

Two different generations of biotite have been distinguished based on microstructures and chemical compositions. Matrix biotite crystals $\left(\mathrm{Bt}_{2}\right)$ are unzoned and have an $X_{\mathrm{Mg}}$ close to 0.38 , and Ti ranging between 0.20 and 0.30 apfu (Tables $\underline{1} \&$ S1). Biotite relicts included in K-feldspar (Fig. 22e) show similar compositions, while the small crystals included in garnet cores $\left(\mathrm{Bt}_{1}\right)$ show higher values of $X_{\mathrm{Mg}}(\sim 0.45$, Table $\underline{1})$.

Plagioclase in the matrix $\left(\mathrm{PI}_{2}\right)$ is homogeneous with a composition close to $A b_{0.78} A n_{0.21} \mathrm{Or}_{0.01}$ (oligoclase). Plagioclase crystals included in garnet cores $\left(\mathrm{Pl}_{1}\right)$ are more enriched in $\mathrm{Ca}$ (andesine, $\mathrm{Ab}_{0.65} \mathrm{An}_{0.34} \mathrm{Or}_{0.01}$, Tables $\underline{1} \& \mathrm{~S} 1$ ). Plagioclase rimming garnet crystals shows the same composition of $\mathrm{PI}_{2}$; no data are available for plagioclase growing in the myrmekitic domains (too thin to be properly analysed). $\mathrm{K}$-feldspar is characterized by intragrain composition ranging between $A b_{0.13} A n_{0.01} \mathrm{Or}_{0.86}$ and $A b_{0.17} A_{0.01} \mathrm{Or}_{0.82}$ (Tables $\underline{1} \& \mathrm{~S} 1$ ).

\section{Trace-element composition of major and accessory phases}

Garnet shows pronounced trace-element zoning patterns (Figs $\underline{4} b$ \& S2; Table S2). The $Y$ and M-HREE content decrease from the core $\left(Y \sim 3000 \mathrm{ppm}, \mathrm{Dy}_{\mathrm{N}} / \mathrm{Yb}_{\mathrm{N}}\right.$ 0.2-0.3) to the rim $(\mathrm{Y} \sim 100 \mathrm{ppm}$, $\mathrm{Dy}_{\mathrm{N}} / \mathrm{Yb}_{\mathrm{N}}$ 1.0-2.0). A similar pattern is shown by the Eu anomaly (Fig. $4 \mathrm{c}$ ) that decreases from core $\left(E u_{N} / E u_{N}^{*}=0.35-0.40\right)$ to $\operatorname{rim}\left(E_{N} / E u_{N}^{*}=0.55-0.60\right)$. At the core-rim transition a subtle increase in trace elements has been observed (Fig. S2).

Zircon internal structure is characterized by large relict cores with oscillatory zoning, overgrown by three distinct rims, which show irregular zoning patterns (Fig. $\underline{5} a$ ). The cores are characterized by high Th/U (0.4-0.8), a strong Eu anomaly ( 0.1 - Fig. $\underline{5}$ a; Table S2) and Ti ranging between 100 and $120 \mathrm{ppm}$. The first, innermost and large rim (rim-I) shows a low CL emission ( $\sim 1200 \mathrm{ppm}$ ), is enriched in HREE at $\sim 500$ times chondrite value, shows only a minor Eu anomaly $\left(\mathrm{Eu}_{\mathrm{N}} / \mathrm{Eu}^{*}{ }_{\mathrm{N}}=0.85-\right.$ 0.90 - Fig. $\underline{5}$ a; Table S2) and has Ti concentrations below detection limit (bdl). The second rim (rimII), thinner in most of the analysed grains, is characterized by low $U$ contents $(<700 \mathrm{ppm})$ and shows similar trace-element composition (two spots, Fig. $\underline{5}$ a) to rim-l; the most external rim (rim-III) shows an enrichment in $\mathrm{U}$ corresponding to low $\mathrm{CL}$ emission. No REE data were collected for rim-III domains as they were generally $<15 \mu \mathrm{m}$ wide and too small for the width of the laser beam. All three rims contain low Th/U ratios ( $<0.01$, Table $\underline{3})$. 
Subhedral grains of monazite (50-250 $\mu \mathrm{m}, 15-20$ grains per thin section) are common in sample DRB1250. The largest grains of monazite include small biotite and quartz crystals. All monazite grains show compositional zoning: $Y$ and Th $X$-ray maps reveal concentric growth zones (Fig. $\underline{5} b$ ). Y-rich cores are characterized by a small Eu anomaly $\left(\mathrm{Eu}_{\mathrm{N}} / \mathrm{Eu}^{*}{ }_{\mathrm{N}} \sim 0.6\right)$ and are depleted in HREE at 100 times chondrite (Fig. $\underline{5}$ b; Table S2). Y-poor mantles show a strong Eu anomaly $\left(E u_{N} / E u^{*}{ }_{N} \sim 0.1\right)$ with a moderate enrichment in HREE at 1000 times chondrite (Fig. $\underline{5} \mathrm{~b}$, Table S2). The monazite mantle is also enriched in Th and $\mathrm{U}$ compared to the monazite core (Table 2). Narrow (5-10 $\mu \mathrm{m}$ ) Y-rich rims are present in all monazite grains but these are too small to be analysed via conventional laser ablation techniques (Fig. $\underline{5}$ b). No compositional data were collected from monazite included in garnet as its size is always $<10 \mu \mathrm{m}$.

\section{Petrological evolution}

Figure $\underline{6}$ illustrates the $P-T$ pseudosections and the metamorphic evolution reconstructed for sample DRB1250. In the two calculated pseudosections, the stable assemblage is represented by the heptavariant field $\mathrm{Bt}+\mathrm{PI}+\mathrm{Grt}+\mathrm{Sil}+\mathrm{Qz}\left(+\mathrm{H}_{2} \mathrm{O}\right)$ at $590<T<700^{\circ} \mathrm{C}$ and $0.45<P<0.75 \mathrm{GPa}$ (Fig. $\underline{6}$ a, b). In the first pseudosection (Fig. $\underline{6}$ a), constraints are given by compositional isopleths of garnet $\left[X_{\mathrm{Mg}}=\mathrm{Mg} /(\mathrm{Mg}+\mathrm{Fe}+\mathrm{Ca}+\mathrm{Mn}), X_{\mathrm{Ca}}=\mathrm{Ca} /(\mathrm{Ca}+\mathrm{Mg}+\mathrm{Fe}+\mathrm{Mn})\right]$ and plagioclase $\left[X_{\mathrm{Na}}=\mathrm{Na} /(\mathrm{Na}+\mathrm{Ca})\right]$. Garnet cores yield $X_{\mathrm{Mg}}$ contents of $0.14-0.15$ and $X_{\mathrm{Ca}}$ of $\sim 0.06$ (Tables $\underline{1} \&$ S1). The calculated isopleths constrain the growth of garnet cores at about $610^{\circ} \mathrm{C}$ and maximum pressures of about $0.55 \mathrm{GPa}$, at the boundary between the kyanite and sillimanite stability fields (Fig. $\underline{6} a$ ). At these conditions $X_{\mathrm{Na}}$ in plagioclase is $\sim 0.68$ and $X_{\mathrm{Mg}}(\mathrm{Mg} / \mathrm{Mg}+\mathrm{Fe})$ in biotite $\sim 0.44$; plagioclase and biotite crystals included in garnet show similar composition with respectively $\sim \mathrm{Ab}_{0.67}\left(\mathrm{Pl}_{1}\right)$ and $X_{\mathrm{Mg}} 0.45\left(\mathrm{Bt}_{1}\right)$ (Tables $\underline{1} \&$ S1). The observed inclusions of prograde ilmenite in the core suggest that garnet cores grew syn-to-post ilmenite crystallization (Fig. $\underline{6} a$ ).

The second pseudosection (Fig. $\underline{6} \mathrm{~b}$ ), calculated to take into account the fractionation effects related to garnet core growth, models the equilibrium assemblage during growth of garnet rims, which are still in equilibrium with biotite, plagioclase, sillimanite and quartz $\left(+\mathrm{H}_{2} \mathrm{O}\right)$. The topology of the high$T$ part of the pseudosection is almost identical to that of Fig. $\underline{6}$; the lower temperature fields differ more. Garnet compositional isopleths for $X_{\mathrm{Mg}}$ and $X_{\mathrm{Ca}}$ overlap at $680^{\circ} \mathrm{C}$ and $0.65 \mathrm{GPa}$. The vol.\% of stable plagioclase in the second pseudosection is lower (11 v. 9\% volume), and the plagioclase has a higher $X_{\mathrm{Na}}$ content ( 0.81$)$, due to consumption of the An-component of plagioclase during garnet growth (e.g. Spear et al., 1990). The modelled isopleths for plagioclase match with the composition of the matrix plagioclase $\left(\mathrm{Pl}_{2}\right.$, Table $\left.\underline{1}\right)$. The modelled $X_{\mathrm{Mg}}$ for biotite $(\sim 0.39-0.4)$ in the constrained field reflect the composition of the matrix biotite $\left(\mathrm{Bt}_{2}\right)$.

Pseudosection models that match the garnet core and rim compositions suggest a prograde $P-$ $T$ path that is characterized by an increase in both temperature and pressure (Fig. $\underline{6} \mathrm{c}$ ). The local occurrence of $\mathrm{K}$-feldspar in reaction domains associated with relicts of biotite, quartz, plagioclase and sillimanite suggests further evolution at higher temperatures above the solidus $\left(>690^{\circ} \mathrm{C}\right)$. Petrographic evidence of partial melting is restricted to narrow leucocratic domains $(<1 \mathrm{~mm})$ in which K-feldspar crystallized and in which back-reaction textures between solid phases and melt occurred. The preservation of abundant sub-solidus phases, the prograde zoning in garnet together with the occurrence of retrograde reactions between solid and melt suggest that the evolution at 
high temperature was probably short-lived with only a small volume of melt production (not enough to exceed the 7 vol.\% melt connectivity transition of Rosenberg \& Handy, 2005).

Along the retrograde path, back-reaction textures involving the growth of myrmekite and sillimanite aggregates around K-feldspar, plagioclase around garnet and the late crystallization of chlorite and white mica are compatible with a cooling decompressional path. Rocks collected nearby and within the same structural level of the GHS (e.g. Kellett et al., 2010; Tobgay et al., 2012) show a similar retrograde evolution, suggesting that sample DRB1250 did not experience the significant isothermal decompression that is evident in neighbouring Sikkim or farther north in Bhutan (e.g.

Ganguly et al., 2000; Warren et al., 2011; Mottram et al., 2014; Sorcar et al., 2014) and which would be indicated by the presence of cordierite/spinel assemblages (e.g. Warren et al., 2011).

\section{Geochronology}

Thirteen analyses of monazite cores (Fig. Z Za) yielded ${ }^{238} \mathrm{U} /{ }^{206} \mathrm{~Pb}$ ages between 35 and $29 \mathrm{Ma}$ (Table 2). Fourteen monazite mantle analyses (Fig. aa) define a population with a ${ }^{238} \mathrm{U} /{ }^{206} \mathrm{~Pb}$ age of $21.7 \pm 0.5 / 0.7 \mathrm{Ma}$ (MSWD $=4$, anchored to a common lead composition of $0.83 \pm 0.02$, Stacey \& Kramers, 1975; Table 2).

Zircon crystals show inherited cores overgrown by three rims (Fig. 가). The core ages scatter between 550 and $850 \mathrm{Ma}$ (Table S3; Fig. S4). The first rims (rim-I) overgrowing the Precambrian cores yield a concordant ${ }^{238} \mathrm{U} /{ }^{206} \mathrm{~Pb}$ age of $38.3 \pm 0.4 / 1.1 \mathrm{Ma}$ (20 analyses, MSWD = 1.5 - Table $\underline{3}$; Fig. 가). The second rim, characterized by high $\mathrm{CL}$ emission, yields a slightly younger (but almost overlapping) ${ }^{238} \mathrm{U} /{ }^{206} \mathrm{~Pb}$ age of $35.6 \pm 0.5 / 1.1$ (eight analyses, MSWD = $1-$ Fig. $\underline{7 b}$; Table $\underline{3}$ ). The most external rims (rim-III) were generally too narrow to be analysed $(<10 \mu \mathrm{m})$. A single spot analysis carried out on rim-III yielded a date $\left({ }^{238} \mathrm{U} /{ }^{206} \mathrm{~Pb}\right)$ of $c .18 \mathrm{Ma}$ (Fig. $\left.\underline{7} \mathrm{~b}\right)$.

\section{Discussion}

\section{Linking metamorphic reactions to accessory phases growth/dissolution}

\section{Early evolution: zircon growth (>36 Ma)}

Zircon in sample DRB1250 is characterized by having large detrital cores (up to $100 \mu \mathrm{m}$ ) with oscillatory zoning. These inherited $800-500 \mathrm{Ma}$ relict cores have a chemical composition that is typical of magmatic zircon: high Th contents and Th/U (0.1-1.0), a REE pattern enriched in HREE and a strong negative Eu anomaly (e.g. Hoskin \& Schaltegger, 2003).

The detrital cores are overgrown by three metamorphic rims, all showing low Th/U ratios $(<0.006$, Table 3 ), which are suggested to be characteristic of metamorphic zircon (e.g. Williams et al., 1996). Zircon rim-I (which is the main metamorphic overgrowth and yields an age of $c$. $38 \mathrm{Ma}$ ) and the few rim-II (c. $36 \mathrm{Ma}$, two trace elements spots) data points show no Eu anomaly. The Ti-content of both rim-I and rim-II is below detection limit, suggesting growth at $<550^{\circ} \mathrm{C}$ (e.g. Watson et al., 2006).

The absence of a Eu anomaly in zircon rim-I and rim-II suggests either that plagioclase was not present during zircon crystallization or that plagioclase was being consumed and therefore releasing Eu into the bulk-rock system. In order to explore which of these options was more likely during the 
early zircon crystallization history, changes in mineral modal proportions were investigated along three idealized $P-T$ trajectories crossing into the stability field of plagioclase (Fig. 10a,b): (i) cooling during decompression, (ii) isothermal decompression and (iii) heating during decompression at $<550^{\circ} \mathrm{C}$. The $P-T$ pseudosections modelled for garnet core and rim show a similar topology; therefore, for practical purposes, phase assemblages and zircon crystallization will be qualitatively discussed using the $P-T$ pseudosection calculated for the bulk composition at the time the garnet core grew.

The destabilization of rutile has been suggested as a mechanism for catalysing zircon growth (Kohnet al., 2015), so the modal abundance of rutile was also calculated in the pseudosection to investigate this possible mechanism for zircon growth. The modal variation diagram (Fig. 10a) shows that rutile is stable in the plagioclase-absent field at $>0.85 \mathrm{GPa}$ and with plagioclase at $<470$ and $>580^{\circ} \mathrm{C}$. The three idealized $P-T$ paths at $>0.85 \mathrm{GPa}$ (Fig $\underline{10 \mathrm{a}}$ ) all suggest rutile destabilization, therefore.

Plagioclase reacts out at $>0.85 \mathrm{GPa}$ and $<630^{\circ} \mathrm{C}$ (Fig. 10 b), and its modal abundance only increases at the time of its first appearance. None of the three investigated $P-T$ trajectories allows plagioclase to be consumed at $<0.85 \mathrm{GPa}$ (Fig. $\underline{10} \mathrm{~b}$ ), unless isobaric heating is assumed - this would be unrealistic in the present case as the sample shows evidence for garnet growth at $\sim 0.55 \mathrm{GPa}$. The pseudosection therefore suggests that the lack of a Eu anomaly in the zircon rims I and II is due to the absence of plagioclase in the assemblage rather than zircon growth during a plagioclaseconsuming episode.

In summary, the trace-element compositions can be used to tentatively reveal the early sample history. We suggest that zircon rims I and II grew under sub-solidus conditions, most likely during a period of isothermal decompression or decompression during heating in a plagioclase-absent, possibly rutile-present environment at $>0.85 \mathrm{GPa}$ and $<550^{\circ} \mathrm{C}$.

Partial dissolution textures along zircon rim-II (Fig. 7), suggest that following sub-solidus zircon rim growth, there was a subsequent period of partial zircon dissolution. This could have been driven partially by solid-state and dehydration reactions at $>570^{\circ} \mathrm{C}$. However, we suggest that most of the dissolution probably occurred when the rock entered the melt stability field (e.g. Kohn et al., 2015). Our interpretation of zircon crystallizing at sub-solidus conditions is contrary to the work of previous studies, which suggests that at sub-solidus conditions zircon should remain relatively unreactive and that the first zircon overgrowths forming during prograde metamorphism in metapelites generally occur during partial melting (e.g. Rubatto et al., 2001; Williams, 2001).

\section{Prograde-to-peak monazite and garnet crystallization (35-29 Ma)}

Garnet is a particularly important and useful metamorphic indicator mineral as it can incorporate high concentrations of various trace elements that potentially record several steps of the rock evolution (e.g. Spear \& Kohn, 1996; Chernoff \& Carlson, 1999). Moreover, inclusions in zoned garnet can be used to determine reactions involving accessory minerals along the prograde path - evidence for which no longer exists in the rock matrix (Fig. 9). In sample DRB1250, garnet is zoned from core to rim in both major and trace elements; thermodynamic models indicate that the garnet grew in the absence of melt from $600{ }^{\circ} \mathrm{C}$ and $0.5 \mathrm{GPa}$ to $680^{\circ} \mathrm{C}$ and $0.65 \mathrm{GPa}$. 
The Eu anomaly in garnet decreases from core to rim (Fig. $\underline{8} a$ ), suggesting that more Eu was available during garnet rim growth than during garnet core growth. This trend can be explained by the breakdown of plagioclase as the anorthite component is consumed during prograde garnet growth (e.g. Spear et al., 1990). Plagioclase ${ }_{1}$ inclusions in the garnet core are associated with tiny xenotime


core therefore likely grew in the presence of allanite and xenotime (Fig. $\underline{9}$ ), while the absence of both accessory phases in the garnet rim might indicate that by the time it grew, allanite and xenotime had broken down. According to our thermodynamic models for garnet growth, the allanite + xenotime-out reaction should have occurred at $>620^{\circ} \mathrm{C}$ (prior to garnet rim growth), which is in agreement with published data for the allanite-to-monazite transition in metapelitic rocks (Palin et al., $\underline{\mathbf{2 0 1 5}}$ and references therein). Note that the trace-element composition of the garnet rim shows a slight increase in $Y$ and HREE; this might support the assertion that garnet rim growth post-dates xenotime breakdown (Figs 4 b \& S2; Table S2).

The monazite core (which crystallized from 35 to $29 \mathrm{Ma}$ ) shows high concentrations of $\mathrm{Y}$, a slightly negative Eu anomaly and a steep HREE pattern resulting in high Gd/Lu ratios (400-1600 - Fig. $\underline{8}$ b). As garnet growth can influence the REE pattern of coexisting minerals, because it preferentially incorporates HREE with respect to the LREE (e.g. Rubatto et al., 2006), we interpret the higher Gd/Lu ratio in the monazite core as an indicator that it grew in the presence of garnet at $<35 \mathrm{Ma}$ (Fig. 10c,d). Moreover, the increase of HREE $+Y$ in garnet rims and the absence of $Y$-phosphate inclusions in the same domains suggest that high-Y monazite cores growth postdates the allanite + xenotime ( \pm apatite?)-out reaction; therefore, the breakdown of $Y$-bearing phases triggers the crystallization of Y-rich monazite with coeval garnet during the sub-solidus prograde evolution. Using the 'old approach' that suggests that high-Y monazite predates garnet growth, we would have interpreted monazite core crystallization as occurring at $>35 \mathrm{Ma}$. In the present case, this interpretation is not valid, and our data suggest that an integrative approach must be used to properly link monazite growth to the prograde metamorphic evolution of the rock.

\section{Partial melting to cooling: monazite and zircon crystallization ( $<29 \mathrm{Ma})$}

Partial melting drives bulk monazite dissolution (e.g. Spear \& Pyle, 2010; Yakymchuk \& Brown, 2014). However, in DRB1250, monazite crystals appear to have been partially preserved during melting. Similar evidence for monazite preservation during high-grade metamorphism in the eastern Himalaya is shown by the presence of pre-Himalayan monazite cores in granuliteamphibolite facies rocks in NW Bhutan and Sikkim (Warren et al., 2011; Mottram et al., 2014). Previous thermodynamic modelling has suggested that if $\sim 20 \%$ of the first melt out of a fertile metapelite were to be removed, the decrease in bulk-rock LREE content would be such that monazite dissolution would occur rapidly with increasing temperature, thus destroying evidence for sub-solidus monazite growth (Kelsey et al., 2008). However, it has also been suggested that the rate of monazite dissolution with increasing temperature may have been overestimated in these models and that monazite dissolution is controlled more strongly by temperature than melt composition (Stepanov et al., 2012). These latter models suggest higher monazite stability at higher temperatures in metapelitic bulk compositions under supra-solidus conditions, allowing sub-solidus monazite (such as the monazite that grew between 35 and $29 \mathrm{Ma}$ in sample DRB1250) to be partially preserved during subsequent melting (e.g. Yakymchuk \& Brown, 2014). 
The low yttrium-concentration monazite mantle (showing a strong Eu anomaly: $E u_{N} / E u_{N}=0.1$ ) grew at c. $21 \mathrm{Ma}$. Among the feldspar minerals, K-feldspar has a stronger positive Eu anomaly than plagioclase (e.g. Bea et al., 1994), which results in a more pronounced negative Eu anomaly in coexisting phases (e.g. Buick et al., 2010). Therefore, we suggest that the monazite mantle (Fig. $\underline{8} \mathrm{~d}$ ) grew in the presence of K-feldspar, most probably during the first stages of melt crystallization (e.g. Hallett \& Spear, 2015; Fig. 10d). The high concentrations of Th and U in the monazite mantle support a suggestion of crystallization in the presence of melt (e.g. Dumond et al., 2015). The mantles are slightly enriched in HREE and are characterized by low Gd/Lu ratios (100-400, Fig. $\underline{8}$ b), suggesting that growth probably occurred at a time when there was no coeval garnet growth, or when growth of peritectic garnet was limited (no peritectic garnet was observed in the studied thin sections, Fig. 10a). Finally, the monazite mantle also shows a higher $\mathrm{Ca} / \mathrm{Sr}$ ratio (Fig. $\underline{8} \mathrm{c}$ ) probably indicating crystallization from a melt enriched in $\mathrm{Ca}$ as a consequence of consumption of plagioclase $(\mathrm{Pl}+\mathrm{Bt}+\mathrm{Als}+\mathrm{Qz}=\mathrm{Kfs} \pm \mathrm{Grt}+$ melt $)$. The geochemical 'fingerprints' preserved in monazite mantles show that the simple assumption in binary systems (monazite-garnet) that low-Y monazite growth occurs at the immediate pre-melting stage is not valid for sample DRB1250.

Five to ten micrometre wide high-Y rims were observed in all monazite crystals. These rims were too thin to be analysed for trace-element composition and age by laser ablation techniques on polished sections, and thus remain undated. Similar narrow rims have been described in the literature and have been interpreted as products of the last melt crystallization resulting from the release of $Y$ during garnet breakdown (e.g. Pyle \& Spear, 2003; Kohn et al., 2005; Tomkins et al., 2005; Kelly et al., 2006).

Small xenotime crystals $(<10 \mu \mathrm{m})$, found in embayments around garnet (Fig. $\underline{9})$, suggest that the breakdown of garnet during the retrograde evolution released enough $Y$ to stabilize xenotime (e.g. Hallett \& Spear, 2015). The garnet breakdown may have occurred at a later stage during sub-solidus retrograde metamorphism; but thus far these xenotime crystals also remain undated.

Zircon rim-III analyses yielded a single spot date of $c .18 \mathrm{Ma}$. Detailed studies that have combined geochronology with trace elements and inclusion relationships have shown that zircon crystallization can occur at the metamorphic peak and/or during decompression or cooling (Vavra et al., 1996; Williams et al., 1996; Degeling et al., 2001; Hermann \& Rubatto, 2003). However, in the presence of melt, isobaric cooling commonly induces melt crystallization, which in turn induces rapid zircon crystallization (e.g. Roberts \& Finger, 1997; Kelsey et al., 2008; Yakymchuk \& Brown, 2014; Kohn et al.,2015). Crystallization of zircon in the supra-solidus therefore post-dates the timing of peak metamorphism (e.g. Roberts \& Finger, 1997). In most of these cases, no zircon growth is observed during cooling because melt drainage completely depletes the source of $\mathrm{Zr}$ (e.g. Kelsey et al., 2008; Yakymchuk \& Brown, 2014). In the present case, where melt production and melt removal is assumed to be limited, the c. $18 \mathrm{Ma}$ zircon rim-III is interpreted as having grown during the last stages of melt crystallization as thin rims on partially resorbed zircon rim-II (Fig. 10 d). We hypothesize that the undated Y-rich monazite rims will yield ages similar to zircon rim-III at c. $18 \mathrm{Ma}$.

In summary, our data suggest that in complex systems involving several accessory phases, the simple interpretation that $Y$ zoning in monazite can be directly linked to reactions involving growth/breakdown of garnet may not be valid and that the interpretation of the petrochronological evolution of a rock must be carefully done on a sample-by-sample basis. 


\section{Timing of metamorphism and partial melting across eastern Himalaya}

Metapelite DRB1250 records an initial cryptic stage in the absence of plagioclase at $\angle 550^{\circ} \mathrm{C}$, $>0.85 \mathrm{GPa}$ and c. $38 \mathrm{Ma}$. This early prograde growth was followed by heating, decompression and a prolonged high- $T$ evolution from 35 to $21 \mathrm{Ma}$ which started with the garnet core growing at $\sim 600^{\circ} \mathrm{C}$ and $0.55 \mathrm{GPa}$ and ended with high-amphibolite facies conditions with small volumes of partial melting, as indicated by the growth of K-feldspar at $>690^{\circ} \mathrm{C}$. The last melt crystallized by $c$. $18 \mathrm{Ma}$. Such a prolonged, $>10 \mathrm{Ma}$, high- $T$ evolution, involving partial melting, has been recorded in both Bhutan and other areas within the Himalaya; however, the detailed 'trace-element fingerprinting' link between the chemical evolution of the major and accessory phases with the petrological evolution of the host rock, has not generally been made in the other studies.

Prograde metamorphic ages $>35 \mathrm{Ma}$ appear to be rare in Bhutan. In central and eastern Bhutan, metapelite zircon rim ages of $c$. 37-28 Ma have been interpreted to have crystallized during prograde sub-solidus evolution (Zeiger et al., 2015). Similarly interpreted texturally controlled prograde ages (35-25 Ma) have been also been documented from the central and western Himalaya (e.g. Hodgeset al., 1996; Vannay \& Hodges, 1996; Yin \& Harrison, 2000; Godin et al., 2001; Leech et al., 2005; Corrie \& Kohn, 2011; Rubatto et al., 2013).

The oldest c. $38 \mathrm{Ma}$ ages preserved in zircon rim-I/-II in DRB1250 are linked chemically to decompression during metamorphism rather than 'prograde' increasing-temperature metamorphism. Our interpretation implies the occurrence of a pre-HT stage at $>0.85 \mathrm{GPa},<550^{\circ} \mathrm{C}$ and $>36 \mathrm{Ma}$ in the absence of plagioclase where zircon crystallization could be triggered by the destabilization of rutile during either isothermal decompression or heating during decompression. It is important to note that even if our interpretation suggests an early evolution at $>0.85 \mathrm{GPa}$, sample DRB1250 does not (now) show any macroscopic evidence for an HP stage metamorphism and the absence of plagioclase does not necessary imply eclogite facies metamorphism. Further samples from the same region may provide complementary data constraining this early metamorphic stage.

A c. 26-23 Ma prograde and c. 20-15 Ma retrograde evolution has been proposed for samples in the immediate footwall of the outer STD at similar structural levels to sample DRB1250 in Western Bhutan (Kellett et al., 2010; Tobgay et al., 2012; Fig. 1b). High-Y monazite rims yielding ages of $c$. 15$10 \mathrm{Ma}$ were interpreted as forming during post-anatectic cooling (Tobgay et al., 2012). The samples described in Kellett et al. (2010) (DBH095, DBH122), collected $20 \mathrm{~km}$ east of sample DRB1250, are similar in mineralogy and microtexture but, according to the described textures and the presence of peritectic garnet, melting was more pervasive. Our prograde monazite ages are slightly older than the prograde monazite ages preserved in the eastern footwall of the outer STD (e.g. Kellett et al., 2010) suggesting that monazite growth may have initiated and progressed earlier in samples DBH095 and DBH122. Evidence for this early evolution was seemingly destroyed by more pervasive melting to the east at c. 23-20 Ma. Zircon preserved in samples DBH095 and DBH122 might also preserve evidence of an earlier stage at $>36 \mathrm{Ma}$, but thus far has not been investigated.

Although our data suggest that rocks at similar structural levels record a similar $P-T-t$ evolution (assuming that published monazite growth ages have been correctly linked to the metamorphic evolution of the samples), it is still unclear how the petrochronological data of sample DRB1250 and the data reported by Kellett et al. (2010) and Tobgay et al. (2012) for the GHS at the O-STD footwall are linkable to the evolution of the neighbouring Jomolhari Massif. The Massif is exposed in a domal 
window in western Bhutan and is juxtaposed against low grade rocks by the Linghsi fault to the east and the normal fault of the Yadong-Gulu graben to the west (Fig. $\underline{1} \mathrm{~b}$ ). The whole massif is characterized by high-grade amphibolite to granulite facies rocks (migmatites, olivine-phologopite marbles and diopside-garnet-scapolite calcsilicates) with extensive melt production (Regis et al., 2014). The evolution of the metapelites of the Jomolhari Massif differs significantly from the evolution of the Paro Chu valley rocks. Monazite crystallization under supra-solidus conditions $\left(>750^{\circ} \mathrm{C}\right.$ ) occurred at c. $35 \mathrm{Ma}$ in the Massif (Regis et al., 2014) while the GHS rocks at the O-STD footwall were recording zircon crystallization at $<550{ }^{\circ} \mathrm{C}$ at the same time.

More petrochronological data are needed to constrain differences in the early metamorphic evolution between the upper and lower structural levels of the GHS and to interpret differences in geological events between the Jomolhari Massif and the GHS in western Bhutan. These data, however, support increasing evidence from elsewhere in the Himalaya that the GHS is a composite package of units that has experienced different metamorphic histories at different times rather than a single coherent history (e.g. Groppo et al., 2009; Imayama et al., 2012; Larson et al., 2013).

\section{Conclusions}

Garnet-bearing metapelites commonly contain chemically zoned accessory phases that yield different age domains. Precise links between the rock $P-T$ evolution and the timing of mineral crystallization still remains the major uncertainty in determining the rates and timescales over which tectonic processes operate both in the Himalayan orogeny and elsewhere.

Trace-element compositions of monazite and zircon, useful geochronometer phases in metamorphic rocks, may reflect the appearance and disappearance of other trace element-bearing phases such as garnet (e.g. via Gd/Lu ratios) and feldspar (via their Eu anomaly). Furthermore, changes in the traceelement composition and inclusion suites in garnet may track the appearance and disappearance of accessory phases such as monazite, xenotime and allanite, which react to form new phases of geochronometric interest. Our data clearly show that the ages and chemical compositions of accessory phases do not necessarily record crystallization during peak metamorphic conditions but rather that their crystallization depends primarily on the bulk-rock composition, the shape of the $P-$ $T$ path and presence or absence of melt. The identification of 'chemical fingerprints' in both accessory phases and major rock-forming minerals is the critical step for linking the ages to the $P-$ $T$ evolution and these data show that monazite and zircon can grow and dissolve independently along the same $P-T$ path.

In Greater Himalayan sample DRB1250, monazite grew over an extended temperature interval at sub-solidus amphibolite facies conditions at $<35 \mathrm{Ma}$ and at $\geq 690^{\circ} \mathrm{C}$ during melt crystallization at $c$. $21 \mathrm{Ma}$. Sub-solidus zircon rims crystallized during a heating episode that involved decompression at $<550^{\circ} \mathrm{C}$ at 38-36 Ma - this older history predated the high- $T$ metamorphism recorded by monazite. The zircon partially re-dissolved during melting and then re-crystallized at c. $18 \mathrm{Ma}$ during the last stages of melt crystallization and cooling.

This study demonstrates that an integrative approach linking several pieces of chemical and petrographic information together helps to unravel details of geochronometer crystallization and dissolution history and must be used in complex systems involving growth/dissolution of several accessory phases. The identification of chemical 'fingerprints' resulting from different accessory 
phase-forming reactions recorded in co-crystallizing major phases such as garnet can help to decipher complex metamorphic evolutions. Further work is still required in order to fully constrain monazite and zircon behaviour during prograde and retrograde metamorphism, under both subsolidus and supra-solidus conditions. The identification of other trace-element chemical 'fingerprints' (not limited to rare earth elements) related to specific metamorphic mineral reactions will make it significantly easier to interpret age data by allowing ages to be linked to specific $P-$ $T$ stages.

\section{Acknowledgments}

This work was financed by Schweizerischer Nationalfonds to DR (Swiss SNF Grant $\mathrm{n}^{\circ}$ PBBEP2_142167), a NERC Advanced Fellowship to C.W. (NE/H016279/1), a NERC studentship to C.M. (NE/1528018/1), and an NIGL steering committee grant to C.W. (IP-1270-1111). In addition, C.W. acknowledges financial support for fieldwork from CEPSAR. D. Young is thanked for fieldwork assistance; $C$. Groppo is thanked for constructive comments about pseudosection modelling. We gratefully acknowledge T. Argles and N. Harris for constructive discussions. A. Tindle and S. Hammond helped in acquiring chemical data with the EMP and LA-ICP-MS at the Open University. Constructive reviews from D. Kellett, A. Martin and an anonymous reviewer improved the manuscript. We thank M. Brown for editorial handling.

\section{References}

- $\quad$ Aleinikoff, J.N., Burton, W.C., Lyttle, P.T. et al., 2000. U-Pb geochronology of zircon and monazite from Mesoproterozoic granitic gneisses of the northern Blue Ridge, Virginia and Maryland, USA. Precambrian Research, 99, 113-146. Bea, F., Pereira, M.D. \& Stroh, A., 1994. Mineral/leucosome trace element partitioning in a peraluminous migmatite (a laser ablation-ICP-MS study). Chemical Geology, 117, 291312.

- $\quad$ Bhowmik, S.K., Wilde, S.A., Bhandari, A. \& Sarbadhikari, A.B., 2014. Zoned monazite and zircon as monitors for the thermal history of granulite terranes: an example from the Central Indian Tectonic Zone. Journal of Petrology, 55, 585-621.

- $\quad$ Buick, I.S., Hermann, J., Williams, I.S. et al., 2006. A SHRIMP U-Pb and LA-ICP-MS trace element study of the petrogenesis of garnet-cordierite-orthoamphibole gneisses from the Central Zone of the Limpopo Belt, South Africa. Lithos, 88, 150-172.

- $\quad$ Buick, I.S., Clark, C., Rubatto, D. et al., 2010. Constraints on the Proterozoic evolution of the AravalliDelhi Orogenic belt (NW India) from monazite geochronology and mineral trace element geochemistry. Lithos, 120,511-528.

- $\quad$ Caddick, M.J., Bickle, M.J., Harris, N.B.W. et al., 2007. Burial and exhumation history of a Lesser Himalayan schist: recording the formation of an inverted metamorphic sequence in NW India. Earth and Planetary Science Letters, 264, 375-390.

- Catlos, E.J., 2013. Versatile monazite: resolving geological records and solving challenges in material science. Generalizations about monazite: implications for geochronologic studies. American Mineralogist, 98, 819-832.

- $\quad$ Chernoff, C.B. \& Carlson, W.D., 1999. Trace element zoning as a record of chemical disequilibrium during garnet growth. Geology, 27, 555-558.

- Connolly, J.A.D., 1990. Multivariable phase diagrams: an algorithm based on generalized thermodynamics.American Journal of Science, 290, 666-718.

- $\quad$ Corrie, S.L. \& Kohn, M.J., 2011. Metamorphic history of the central Himalaya, Annapurna region, Nepal, and implications for tectonic models. Geological Society of American Bulletin, 123, 1863-1879.

- Corrie, S.L., Kohn, M.J., McQuarrie, N. \& Long, S.P., 2012. Flattening the Bhutan Himalaya. Earth and Planetary Science Letters, 349-350, 67-74.

- Cottle, J.M., Searle, M.P., Horstwood, M.S.A. et al., 2009. Timing of midcrustal metamorphism, melting, and deformation in the Mount Everest region of Southern Tibet revealed by $\mathrm{U}(-\mathrm{Th})-\mathrm{Pb}$ geochronology. The Journal of Geology, 117, 643-664.

- $\quad$ Cottle, J.M., Larson, K.P. \& Kellett, D.A., 2015. How does the mid-crust accommodate deformation in large, hot collisional orogens? A review of recent research in the Himalayan orogeny. Journal of Structural Geology, 78,119-133. 
- Daniel, C.G., Hollister, L.S., Parrish, R.R. et al., 2003. Exhumation of the Main Central Thrust from lower crustal depths, Eastern Bhutan Himalaya. Journal of Metamorphic Geology, 21, 317-334.

- Davidson, C., Grujic, D.E., Hollister, L.S. et al., 1997. Metamorphic reactions related to decompression and synkinematic intrusion of leucogranite, High Himalayan Crystallines, Bhutan. Journal of Metamorphic Geology,15, 593-612.

- $\quad$ DeCelles, P.G., Kapp, P., Gehrels, G.E. \& Ding, L., 2014. Paleocene-Eocene foreland basin evolution in the Himalaya of southern Tibet and Nepal: implications for the age of initial India-Asia collision. Tectonics, 33,824-849.

- Degeling, H., Eggins, S. \& Ellis, D.J., 2001. Zr budgets for metamorphic reactions, and the formation of zircon from garnet breakdown. Mineralogical Magazine, 65, 749-758.

- Dumond, G., Goncalves, P., Williams, M.L. \& Jercinovic, M.J., 2015. Monazite as a monitor of melting, garnet growth and feldspar recrystallization in continental lower crust. Journal of Metamorphic Geology, 33, 735-762.

- $\quad$ Evans, T.P., 2004. A method for calculating effective bulk composition modification due to crystal fractionation in garnet-bearing schist: implication for isopleth thermobarometry. Journal of Metamorphic Geology, 22,547-557.

- $\quad$ Ferry, J.M. \& Watson, E.B., 2007. New thermodynamic models and revised calibrations for the Ti-inzircon and Zr-inrutile thermometers. Contributions to Mineralogy and Petrology, 154, 429-437.

o CrossRef |

- Foster, G., Gibson, H.D., Parrish, R. et al., 2002. Textural, chemical and isotopic insights into the nature and behaviour of metamorphic monazite. Chemical Geology, 191, 183-207.

- Foster, G., Parrish, R.R., Horstwood, M.S.A. et al., 2004. The generation of prograde P-T-t points and paths; a textural, compositional, and chronological study of metamorphic monazite. Earth and Planetary Science Letters,228, 125-142.

- $\quad$ Gaidies, F., Abart, R., De Capitani, C. et al., 2006. Characterization of polymetamorphism in the Austroalpine basement east of the Tauern Window using garnet isopleth thermobarometry. Journal of Metamorphic Geology,24, 451-475.

- Ganguly, J., Dasgupta, S., Cheng, W. \& Neogi, S., 2000. Exhumation history of a section of the Sikkim Himalayas, India: records in the metamorphic mineral equilibria and compositional zoning in garnet. Earth and Planetary Science Letters, 183, 471-486.

- Gansser, A., 1964. Geology of the Himalayas. Wiley Interscience, London.

- Gansser, A., 1983. Geology of the Bhutan Himalaya. Birkhauser Verlag, Basel.

- Gasser, D., Jeřàbek, P., Faber, C. et al., 2015. Behaviour of geochronometers and timing of metamorphic reactions during deformation at lower crustal conditions: phase equilibrium modelling and $\mathrm{U}-\mathrm{Pb}$ dating of zircon, monazite, rutile and titanite from the Kalak Nappe Complex, northern Norway. Journal of Metamorphic Geology, 33, 513-534.

- $\quad$ Gibson, H.D., Carr, S.D., Brown, R.L. et al., 2004. Correlations between chemical and age domains in monazite, and metamorphic reactions involving major pelitic phases: an integration of ID-TIMS and SHRIMP geochronology with Y-Th-U X-ray mapping. Chemical Geology, 211, 237-260.

- Godin, L., Parrish, R.R., Brown, R.L. \& Hodges, K.V., 2001. Crustal thickening leading to exhumation of the Himalayan Metamorphic core of central Nepal: insight from U-Pb Geochronology and Ar40/Ar39 Thermochronology. Tectonics, 20, 729-747.

- $\quad$ Gordon, S.M., Grove, M., Whitney, D.L. et al., 2009. Fluid-rock interaction in orogenic crust tracked by zircon depth profiling. Geology, 37, 735-738.

- Gratz, R. \& Heinrich, W., 1997. Monazite-xenotime thermobarometry: experimental calibration of the miscibility gap in the system CePO4-YPO4. American Mineralogist, 82, 772-780.

- Greenwood, L.V. 2013. Orogenesis in the Eastern Himalaya: a study of structure, geochronology and metamorphism in Bhutan. Unpublished PhD thesis, The Open University, UK 460 pp.

- Groppo, C., Rolfo, F. \& Lombardo, B., 2009. P-T evolution across the Main Central Thrust Zone (Eastern Nepal): hidden discontinuities revealed by petrology. Journal of Petrology, 50, 1149-1180.

- Groppo, C., Rolfo, F. \& Indares, A., 2012. Partial melting in the Higher Himalayan Crystallines of Eastern Nepal: the effect of decompression and implications for the 'Channel Flow' model. Journal of Petrology, 53, 1057-1088.

- $\quad$ Grujic, D., Hollister, L.S. \& Parrish, R.R., 2002. Himalayan metamorphic sequence as an orogenic channel: insight from Bhutan. Earth and Planetary Science Letters, 198, 177-191.

- Guilmette, C., Indares, A. \& Hébert, R., 2011. High-pressure anatectic metapelites from the Namche Barwa, Eastern Himalayan Syntaxis: textural evidence for partial melting, phase equilibria modelling and tectonic implications. Lithos, 124, 66-81.

- Hallett, B.W. \& Spear, F.S., 2015. Monazite, zircon, and garnet growth in migmatitic pelites as a record of metamorphism and partial melting in the East Humboldt Range, Nevada. American Mineralogist, 100, 951-972.

- Harrison, T.M. \& Watson, E.B., 1983. Kinetics of zircon dissolution and zirconium diffusion in granitic melts of variable water content. Contributions to Mineralogy and Petrology, 84, 66-72. 
- Heim, A. \& Gansser, A., 1939. Central Himalayas-Geological observations of Swiss expedition, 1936. Memoires de la Société Helvetique des Sciences Naturelles, 73, 1-245.

- Heinrich, W., Andrehs, G. \& Franz, G., 1997. Monazite-xenotime miscibility gap thermometry. I. An empirical calibration. Journal of Metamorphic Geology, 15, 3-16.

- Hermann, J. \& Rubatto, D., 2003. Relating zircon and monazite domains to garnet growth zones: age and duration of granulite facies metamorphism in the Val Malenco lower crust. Journal of Metamorphic Geology, 21,833-852.

- Hodges, K.V., Parrish, R.R. \& Searle, M.P., 1996. Tectonic evolution of the central Annapurna Range, Nepalese Himalayas. Tectonics, 15, 1264-1291.

- Holder, R.M., Hacker, B.R., Kylander-Clark, A.R.C. et al., 2015. Monazite trace-element and isotopic signatures of (ultra)high-pressure metamorphism: examples from the Western Gneiss Region, Norway. Chemical Geology,409, 99-111.

- $\quad$ Holland, T.J.B. \& Powell, R., 1998. An internally consistent thermodynamic data set for phases of petrologic interest. Journal of Metamorphic Geology, 16, 309-343.

- Holland, T.J.B. \& Powell, R., 2001. Calculation of phase relations involving haplogranitic melts using an internally consistent thermodynamic dataset. Journal of Petrology, 42, 673-683.

- Holland, T., Baker, J. \& Powell, R., 1998. Mixing properties and activity-composition relationships of chlorites in the system MgO-FeO- $\mathrm{Al}_{2} \mathrm{O}_{3}-\mathrm{SiO}_{2}-\mathrm{H}_{2} \mathrm{O}$. European Journal of Mineralogy, 10, 395-406.

- Horn, I., Hinton, R.W., Jackson, S.E. et al., 1997. Ultra-trace element analysis of NIST SRM 616 and 614 using laser ablation microprobe-inductively coupled plasma-mass spectrometry (LAM-ICP-MS): a comparison with secondary ion mass spectrometry (SIMS). Geostandards Newsletter, 21, 191-203.

- Hoskin, P.W.O. \& Schaltegger, U., 2003. The composition of zircon and igneous and metamorphic petrogenesis. Reviews in Mineralogy and Geochemistry, 53, 27-62.

- Hu, X., Garzanti, E., Moore, T. \& Raffi, I., 2015. Direct stratigraphic dating of India-Asia collision onset at the Selandian (middle Paleocene, $59 \pm 1 \mathrm{Ma}$ ). Geology, 43, 859-862.

- Imayama, T., Takeshita, T., Yi, K. et al., 2012. Two-stage partial melting and contrasting cooling history within the Higher Himalayan Crystalline Sequence in the far-eastern Nepal Himalaya. Lithos, 134$135,1-22$.

- Jamieson, R.A., Beaumont, C., Medvedev, S. \& Nguyen, M.H., 2004. Crustal channel flows: 2. Numerical models with implications for metamorphism in the Himalayan-Tibetan Orogen. Journal of Geophysical Research, 109,B06406.

- Jamieson, R.A., Beaumont, C., Nguyen, M.H. \& Grujic, D., 2006. Provenance of the greater Himalayan sequence and associated rocks: predictions of channel flow models. In: Channel Flow, Ductile Extrusion and Exhumation in Continental Collision Zones (eds Law, R.D., Searle, M.P. \& Godin, L.), Geological Society of London Special Publications, 268, 165-182.

- $\quad$ Kellett, D.A., Grujic, D. \& Erdmann, S., 2009. Miocene structural reorganization of the South Tibetan detachment, eastern Himalaya: implications for continental collision. Lithosphere, 1, 259-281.

- Kellett, D.A., Grujic, D., Warren, C. et al., 2010. Metamorphic history of a syn-convergent orogen-parallel detachment: the South Tibetan detachment system, Bhutan Himalaya. Journal of Metamorphic Geology, 28,785-808.

- $\quad$ Kellett, D.A., Cottle, J.M. \& Smit, M. 2014. Eocene deep crust at Ama Drime, Tibet: Early evolution of the Himalayan orogen. Lithosphere, 6, 220-229.

- $\quad$ Kelly, N.M., Clarke, G.L. \& Harley, S.L., 2006. Monazite behaviour and age significance in polymetamorphic high-grade terrains: a case study from the western Musgrave Block, central Australia. Lithos, 88, 100-134.

- Kelly, N.M., Harley, S.L. \& Möller, A., 2012. Complexity in the behavior and recrystallization of monazite during high-T metamorphism and fluid infiltration. Chemical Geology, 322-323, 192-208.

- Kelsey, D.E. \& Powell, R., 2011. Progress in linking accessory mineral growth and breakdown to major mineral evolution in metamorphic rocks: a thermodynamic approach in the $\mathrm{Na}_{2} \mathrm{O}-\mathrm{CaO}-\mathrm{K}_{2} \mathrm{O}-\mathrm{FeO}-\mathrm{MgO}-$ $\mathrm{Al}_{2} \mathrm{O}_{3}-\mathrm{SiO}_{2}-\mathrm{H}_{2} \mathrm{O}-\mathrm{TiO}_{2}-\mathrm{ZrO}_{2}$ system. Journal of Metamorphic Geology, 29, 151-166.

- Kelsey, D.E., Powell, R., Wilson, C.J.L. et al., 2003. (Th+U)-Pb monazite ages from Al-Mg-rich metapelites, Rauer Group, east Antarctica. Contributions to Mineralogy and Petrology, 146, 326-340.

- Kelsey, D.E., Clark, C. \& Hand, M., 2008. Thermobarometric modelling of zircon and monazite growth in melt-bearing systems: examples using model metapelitic and metapsammitic granulites. Journal of Metamorphic Geology, 26, 199-212.

- Kohn, M.J., 2008. P-T-t data from central Nepal support critical taper and repudiate large-scale channel flow of the Greater Himalayan sequence. Geological Society of America Bulletin, 120, 259-273.

- Kohn, M.J. \& Malloy, M.A., 2004. Formation of monazite via prograde metamorphic reactions among common silicates: implications for age determinations. Geochimica and Cosmochimica Acta, 68, 101113.

- Kohn, M.J., Wieland, M.S., Parkinson, C.D. \& Upreti, B.N., 2004. Miocene faulting at plate tectonic velocity in the Himalaya of central Nepal. Earth and Planetary Science Letters, 228, 299-310. 
- $\quad$ Kohn, M.J., Wieland, M.S., Parkinson, C.D. \& Upreti, B.N., 2005. Five generations of monazite in Langtang gneisses: implications for chronology of the Himalayan metamorphic core. Journal of Metamorphic Geology, 23,399-406.

- Kohn, M.J., Corrie, S.L. \& Markley, C., 2015. The fall and rise of metamorphic zircon. American Mineralogist, 100,897-908.

- $\quad$ Larson, K.P., Gervais, F. \& Kellett, D.A., 2013. A P-T-t-D discontinuity in east-central Nepal: implications for the evolution of the Himalayan mid-crust. Lithos, 179, 275-292.

- $\quad$ Larson, K.P., Ambrose, T.K., Webb, A.A.G. et al., 2015. Reconciling Himalayan midcrustal discontinuities: the Main Central thrust system. Earth and Planetary Science Letters, 429, 139-146.

- Leech, M.L., Singh, S., Jain, A.K. et al., 2005. The onset of India-Asia continental collision: Early, steep subduction required by the timing of UHP metamorphism in the western Himalaya. Earth and Planetary Science Letters, 234, 83-97.

- $\quad$ Leger, R.M., Webb, A.A.G., Henry, D.J. et al., 2013. Metamorphic field gradients across the Himachal Himalaya, northwest India: implications for the emplacement of the Himalayan crystalline core. Tectonics, 32, 540-557.

- $\quad$ Ludwig, K.R. 2003. Isoplot/Ex version 3.0. A Geochronological Toolkit for Microsoft Excel. Berkeley Geochronological Centre Special Publications, Berkeley, CA.

- Majka, J., Be'eri-Shlevin, Y., Gee, D.G. et al., 2012. Multiple monazite growth in the Åreskutan migmatite: evidence for a polymetamorphic Late Ordovician to Late Silurian evolution in the Seve Nappe Complex of west-central Jämtland, Sweden. Journal of Geosciences, 57, 3-23.

- Martin, A.J., Gehrels, G.E. \& DeCelles, P.G., 2007. The tectonic significance of (U, Th)/Pb ages of monazite inclusions in garnet from the Himalaya of central Nepal. Chemical Geology, 244, 1-24.

- McDonough, W.F. \& Sun, S.-S., 1995. The composition of the earth. Chemical Geology, 120, $223-253$.

- McQuarrie, N., Robinson, D., Long, S. et al., 2008. Preliminary stratigraphic and structural architecture of Bhutan: implications for the along strike architecture of the Himalayan system. Earth and Planetary Science Letters, 272, 105-117.

- $\quad$ Möller, A., O'Brien, P.J., Kennedy, A. \& Kröner, A., 2003. Linking growth episodes of zircon and metamorphic textures to zircon chemistry: an example from the ultrahigh-temperature granulites of Rogaland (SW Norway).Geological Society, London, Special Publications, 220, 65-81.

- Mottram, C.M., Warren, C.J., Regis, D. et al., 2014. Developing an inverted Barrovian sequence: insights from monazite petrochronology. Earth and Planetary Science Letters, 403, 418-431.

- Mottram, C.M., Parrish, R.R., Regis, D. et al., 2015. Using U-Th-Pb petrochronology to determine rates of ductile thrusting: Time windows into the Main Central Thrust, Sikkim Himalaya. Tectonics, 34, 13551374.

- $\quad$ Newton, R.C., Charlu, T.V. \& Kleppa, O.J., 1980. Thermochemistry of the high structural state plagioclase.Geochimica and Cosmochimica Acta, 44, 933-941.

- $\quad$ Palin, R.M., Searle, M.P., Waters, D.J. et al., 2013. A geochronological and petrological study of anatectic paragneiss and associated granite dykes from the Day Nui Con Voi metamorphic core complex, North Vietnam: constraints on the timing of metamorphism within the Red River shear zone. Journal of Metamorphic Geology, 31, 359-387.

- Palin, R.M., Searle, M.P., St-Onge, M.R. et al., 2015. Two-stage cooling history of politic and semi-pelitic mylonite (sensu lato) from the Dongjiu-Milin shear zone, northwest flank of the eastern Himalayan syntaxis. Gondwana Research, 28, 509-530.

- $\quad$ Pearce, N.J.G., Perkins, W.T., Westgate, J.A. et al., 1997. A compilation of new and published major and trace element data for NIST SRM 610 and NIST SRM 612 glass reference materials. Geostandards Newsletter, 21,115-144.

- Powell, C.Mc.A \& Conaghan, P.J., 1973. Plate tectonics and the Himalayas. Earth and Planetary Science Letters, 20, 1-12.

- $\quad$ Pownceby, M.I., Wall, V.J., O'Neil, H. \& St, C., 1987. Fe-Mn partitioning between garnet and ilmenite: experimental calibration and applications. Contributions to Mineralogy and Petrology, 97, 116-126.

- $\quad$ Pyle, J.M. \& Spear, F.S., 2000. An empirical garnet (YAG) \pm xenotime thermometer. Contributions to Mineralogy and Petrology, 138, 51-58.

- $\quad$ Pyle, J.M. \& Spear, F.S., 2003. Four generations of accessory phase growth in low pressure migmatites from SW New Hampshire. American Mineralogist, 88, 338-351.

- $\quad$ Pyle, J.M., Spear, F.S., Rudnick, R.L. \& McDonough, W.F., 2001. Monazite-xenotime-garnet equilibrium in metapelites and a new monazite-garnet thermometer. Journal of Petrology, 42, 20832107.

- $\quad$ Regis, D., Warren, C.J., Young, D. \& Roberts, N.M.W., 2014. Tectono-metamorphic evolution of the Jomolhari massif: variations in timing of syn-collisional metamorphism across western Bhutan. Lithos, 190-191, 449-466.

- $\quad$ Roberts, M.P. \& Finger, F., 1997. Do U-Pb zircon ages from granulites reflect peak metamorphic conditions?Geology, 25, 319-322. 
- Rosenberg, C.L. \& Handy, M.R., 2005. Experimental deformation of partially melted granite revisited: implications for the continental crust. Journal of Metamorphic Geology, 23, 19-28.

- Rubatto, D., Williams, I.S. \& Buick, I.S., 2001. Zircon and monazite response to prograde metamorphism in the Reynolds Range, central Australia. Contributions to Mineralogy and Petrology, 140, 458-468.

- Rubatto, D., Hermann, J. \& Buick, I.S., 2006. Temperature and bulk composition control on the growth of monazite and zircon during low-pressure anatexis (Mount Stafford, Central Australia). Journal of Petrology, 47,1973-1996.

- $\quad$ Rubatto, D., Chakraborty, S. \& Dasgupta, S., 2013. Timescales of crustal melting in the Higher Himalayan Crystallines (Sikkim, Eastern Himalaya) inferred from trace element-constrained monazite and zircon chronology. Contributions to Mineralogy and Petrology, 165, 349-372.

- $\quad$ Sawyer, E.W., 2008. Atlas of Migmatites. The Canadian Mineralogist, Special Publication, 9. NRC Research Press, Ottawa, ON, 371 pp.

- Searle, M.P., Simpson, R.L., Law, R.D. et al., 2003. The structural geometry, metamorphic and magmatic evolution of the Everest massif, High Himalaya of Nepal-South Tibet. Journal of the Geological Society, 160,345-366.

- Searle, M.P., Law, R.D. \& Jessup, M.J., 2006. Crustal structure, restoration and evolution of the Greater Himalaya in Nepal-South Tibet: implications for channel flow and ductile extrusion of the middle crust. In:Channel Flow, Ductile Extrusion and Exhumation in Continental Collision Zones (eds Law, R.D., Searle, M.P. \&Godin, L.), Geological Society of London Special Publications, 268, 355-378.

- $\quad$ Seeber, L. \& Armbruster, J.G., 1981. Great detachment earthquakes along the Himalayan arc and longterm forecasting. In: Earthquake Prediction: An International Review (eds Simpson, D.W. \& Richards, P.G.), pp.259-277. American Geophysical Union, Washington, DC.

- Simpson, R.L., Parrish, R.R., Searle, M.P. et al., 2000. Two episodes of monazite crystallization during metamorphism and crustal melting in the Everest region of the Nepalese Himalaya. Geology, 28, 403406.

- Smit, M.A., Hacker, B.R. \& Lee, J., 2014. Tibetan garnet records early Eocene initiation of thickening in the Himalaya. Geology, 42, 591-594.

- Sorcar, N., Hoppe, U., Dasgupta, S. \& Chakraborty, S., 2014. High-temperature cooling histories of migmatites from the High Himalayan Crystallines in Sikkim, India: rapid cooling unrelated to exhumation? Contributions to Mineralogy and Petrology, 167, 1-34.

- $\quad$ Spear, F.S. \& Kohn, M.J., 1996. Trace element zoning in garnet as a monitor of crustal melting. Geology, 24,1099-1102.

- Spear, F.S. \& Pyle, J.M., 2002. Apatite, monazite, and xenotime in metamorphic rocks. In: Phosphates: Geochemical, Geobiological, and Materials Importance (eds Kohn, M.J., Rakovan, J. \& Hughes, J.M.), Reviews in Mineralogy and Geochemistry, 48, 293-335.

- $\quad$ Spear, F.S. \& Pyle, J.M., 2010. Theoretical modeling of monazite growth in a low-Ca metapelite. Chemical Geology, 273, 111-119.

- $\quad$ Spear, F.S., Kohn, M.J., Florence, F.P. et al., 1990. A model for garnet and plagioclase growth in pelitic schists: implications for thermobarometry and $P-T$ path determinations. Journal of Metamorphic Geology, 8, 683-696.

- Spencer, C.J., Prave, A.R., Cawood, P.A. \& Roberts, N.M.W., 2014. Detrital zircon geochronology of the Grenville/Llano foreland and basal Sauk Sequence in West Texas, USA. Geological Society of America Bulletin,126, 1117-1128.

- $\quad$ Stacey, J.S. \& Kramers, J.D., 1975. Approximation of terrestrial lead evolution by a two-stage model. Earth and Planetary Science Letters, 26, 207-221.

- $\quad$ Stepanov, A.S., Hermann, J., Rubatto, D. \& Rapp, R.P., 2012. Experimental study of monazite/melt partitioning with implications for the REE, Th and U geochemistry of crustal rocks. Chemical Geology, 300-301, 200-220.

- Tajcmanová, L., Connolly, J.A.D. \& Cesare, B., 2009. A thermodynamic model for titanium and ferric iron solution in biotite. Journal of Metamorphic Geology, 27, 153-164.

- Thompson, J.B. \& Hovis, G.L., 1979. Entropy of mixing in sanidine. American Mineralogist, 64, 57-65.

- Tinkham, D.K. \& Ghent, E.D., 2005. Estimating P-Tconditions of garnet growth with isochemical phasediagram sections and the problem of effective bulk-composition. Canadian Mineralogist, 43, 35-50.

- $\quad$ Tobgay, T., McQuarrie, N., Long, S.P. et al., 2012. The age and rate of displacement along the Main Central Thrust in the western Bhutan Himalaya. Earth and Planetary Science Letters, 319-320, 146158.

- $\quad$ Tomkins, H.S., Williams, I.S. \& Ellis, D.J., 2005. In situ U-Pb dating of zircon formed from retrograde garnet breakdown during decompression in Rogaland, SW Norway. Journal of Metamorphic Geology, 23, 201-215.

- Vannay, J.C. \& Hodges, K., 1996. Tectonometamorphic evolution of the Himalayan metamorphic core between Annapurna and Dhaulagiri, central Nepal. Journal of Metamorphic Geology, 14, 635-656. 
- Vavra, G., Gebauer, D., Schmid, R. et al., 1996. Multiple zircon growth and recrystallization during polyphase Late Carboniferous to Triassic metamorphism in granulites of the Ivrea Zone (Southern Alps): an ion microprobe (SHRIMP) study. Contributions to Mineralogy and Petrology, 122, 337-358.

- Warren, C.J., Grujic, D., Kellett, D.A. et al., 2011. Probing the depths of the India-Asia collision: U-Th$\mathrm{Pb}$ monazite chronology of granulites from NW Bhutan. Tectonics, 30, TC2004. doi:10.1029/2010TC002738.

- Watson, E.B., Wark, D.A. \& Thomas, J.B., 2006. Crystallization thermometers for zircon and rutile. Contributions to Mineralogy and Petrology, 151, 413-433.

- Webb, A.A.G., Yin, A., Harrison, T.M. et al., 2007. The leading edge of the Greater Himalayan Crystalline complex revealed in the NW Indian Himalaya: implications for the evolution of the Himalayan orogen. Geology,35, 955-958.

- Webb, A.A.G., Schmitt, A.K., He, D. \& Weigand, E.L., 2011. Structural and geochronological evidence for the leading edge of the Greater Himalayan Crystalline complex in the central Nepal Himalaya. Earth and Planetary Science Letters, 304, 483-495.

- White, R.W., Powell, R., Holland, T.J.B. et al., 2000. The effect of $\mathrm{TiO}_{2}$ and $\mathrm{Fe}_{2} \mathrm{O}_{3}$ on metapelitic assemblages at greenschist and amphibolite facies conditions: mineral equilibria calculations in the syste $\mathrm{K}_{2} \mathrm{O}-\mathrm{FeO}-\mathrm{MgO}-\mathrm{Al}_{2} \mathrm{O}_{3}-\mathrm{SiO}_{2}-\mathrm{H}_{2} \mathrm{O}-\mathrm{TiO}_{2}-\mathrm{Fe}_{2} \mathrm{O}_{3}$. Journal of Metamorphic Geology, 18, 497-511.

- White, R.W., Powell, R. \& Holland, T.J.B., 2001. Calculation of partial melting equilibria in the system $\mathrm{Na}_{2} \mathrm{O}-\mathrm{CaO}-\mathrm{K}_{2} \mathrm{O}-\mathrm{FeO}-\mathrm{MgO}-\mathrm{Al}_{2} \mathrm{O}_{3}-\mathrm{SiO}_{2}-\mathrm{H}_{2} \mathrm{O}$ (NCKFMASH). Journal of Metamorphic Geology, 19, 139 153.

- Whitney, D.L. \& Evans, B.W., 2010. Abbreviations for names of rock-forming minerals. American Mineralogist,95, 185-187.

- Williams, I.S., 2001. Response of detrital zircon and monazite, and their U-Pb isotopic systems, to regional metamorphism and host-rock partial melting, Cooma Complex, southeastern Australia. Australian Journal of Earth Sciences, 48, 557-580.

- Williams, I.S., Buick, I.S. \& Cartwright, I., 1996. An extended episode of early Mesoproterozoic metamorphic fluid flow in the Reynolds Range, central Australia. Journal of Metamorphic Geology, 14, 29-47.

- $\quad$ Wing, B.N., Ferry, J.M. \& Harrison, T.M., 2003. Prograde destruction and formation of monazite and allanite during contact and regional metamorphism of pelites: petrology and geochronology. Contributions to Mineralogy and Petrology, 145, 228-250.

- Yakymchuk, C. \& Brown, M., 2014. Behaviour of zircon and monazite during crustal melting. Journal of the Geological Society of London, 171, 465-479.

- $\quad$ Yang, P. \& Pattison, D., 2006. Genesis of monazite and Y zoning in garnet from the Black Hills, South Dakota.Lithos, 88, 233-253.

- Yin, A. \& Harrison, T.M., 2000. Geologic evolution of the Himalayan-Tibetan orogeny. Annual Review of Earth and Planetary Sciences, 28, 211-280.

- Zeh, A., 2001. Inference of a detailed P-T path from P-T pseudosections using metapelitic rocks of variable composition from a single outcrop, Shackleton Range, Antarctica. Journal of Metamorphic Geology, 19, 329-350.

- Zeh, A., Williams, I.S., Braetz, H. et al., 2003. Different age response of zircon and monazite during the tectono-metamorphic evolution of a high grade paragneiss from the Ruhla Crystalline Complex, central Germany. Contributions to Mineralogy and Petrology, 145, 691-706.

- Zeiger, K., Gordon, S.M., Long, S.P. et al., 2015. Timing and conditions of metamorphism and melt crystallization in Greater Himalayan rocks, eastern and central Bhutan: insight from U-Pb zircon and monazite geochronology and trace-element analyses. Contributions to Mineralogy and Petrology, 169, 1-47.

- Zhu, B., Kidd, F.F., Rowley, D.B. et al., 2005. Age of initiation of the India-Asia collision in the EastCentral Himalayas. Journal of Geology, 113, 265-285. 

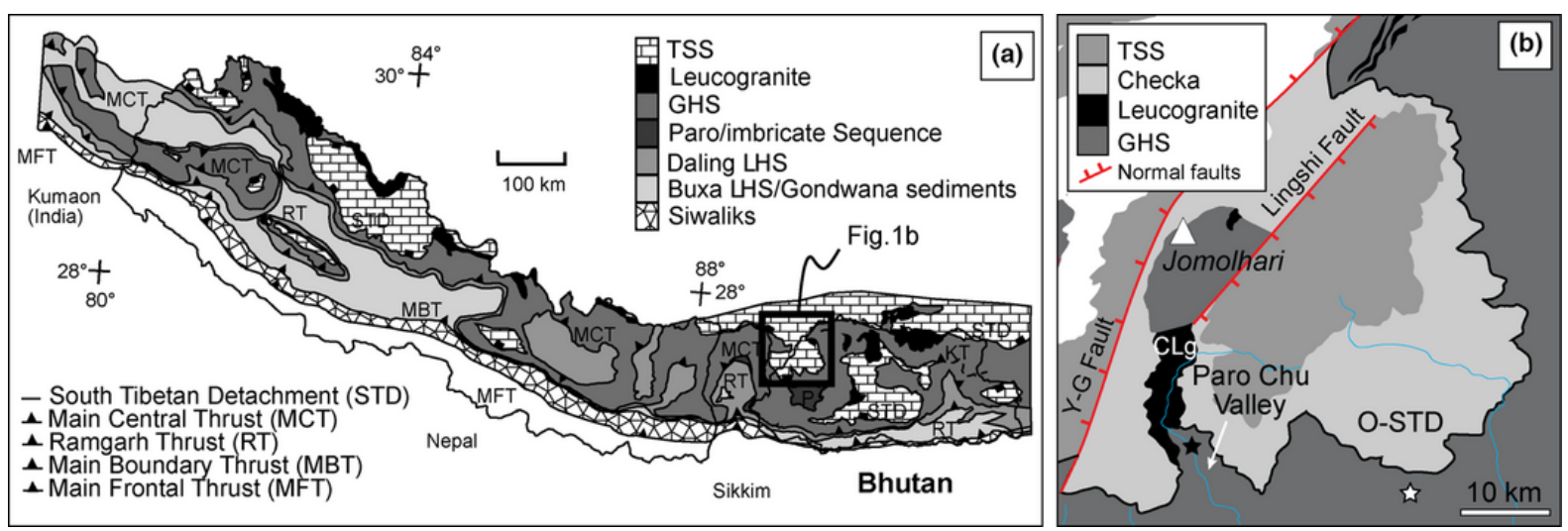

Fig. 1.

(a) Geological map of the Himalayan orogen modified after McQuarrie et al. ([1] ) and Greenwood ([2]). P, Paro window; KT, Kakthang Thrust. (b) Simplified geological map of NW Bhutan (modified after Grujic et al., [3]; Kellett et al., [4]; Regis et al., [5]). Black star: sample DRB1250, white star: samples presented in Kellett et al. ([6]) and Tobgay et al. ([7]). CLg, Chung La granite; O-STD, 'outer' South Tibetan Detachment; Y-G fault, Yadong-Gulu normal fault.
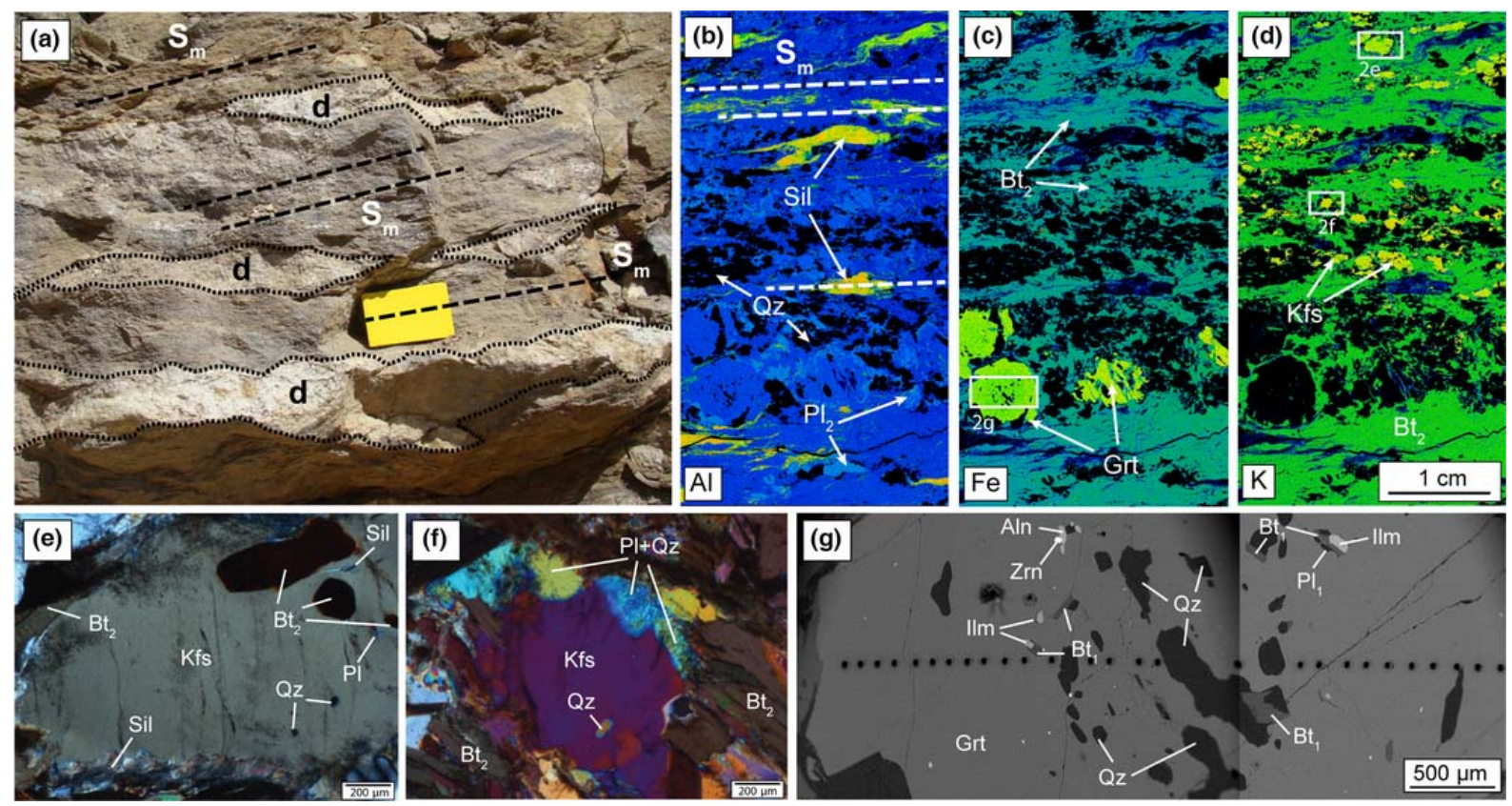

Fig. 2. (a) Geological map of the Himalayan orogen modified after McQuarrie et al. ([1]) and

Greenwood ([2]). P, Paro window; KT, Kakthang Thrust. (b) Simplified geological map of NW Bhutan (modified after Grujic et al., [3]; Kellett et al., [4]; Regis et al., [5]). Black star: sample DRB1250, white star: samples presented in Kellett et al. ([6]) and Tobgay et al. ([7]). CLg, Chung La granite; O-STD, 'outer' South Tibetan Detachment; Y-G fault, Yadong-Gulu normal fault. 


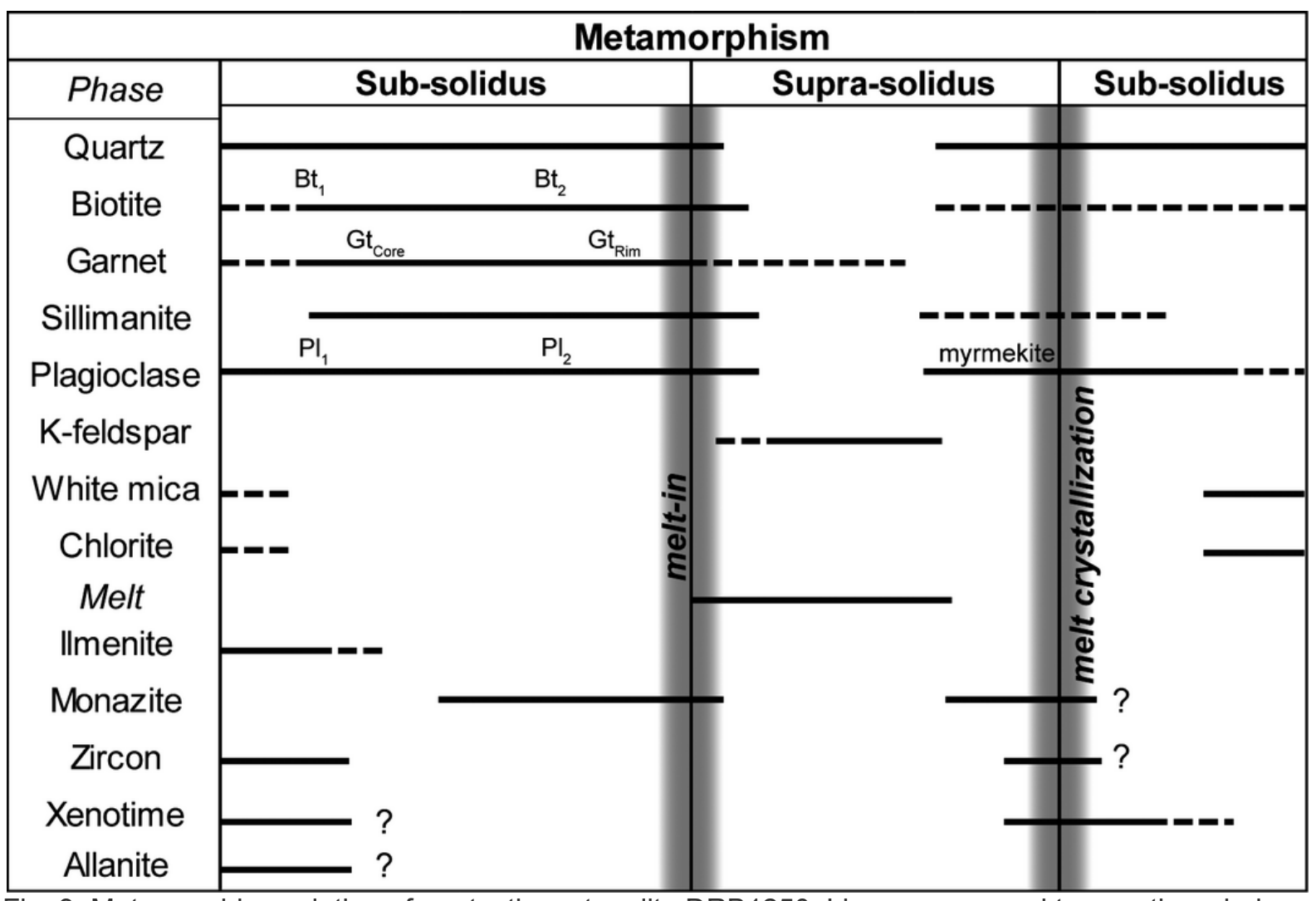

Fig. 3. Metamorphic evolution of anatectic metapelite DRB1250. Lines correspond to growth periods for each phase during the reconstructed metamorphic history. Solid line: growth; dashed line: inferred growth. 

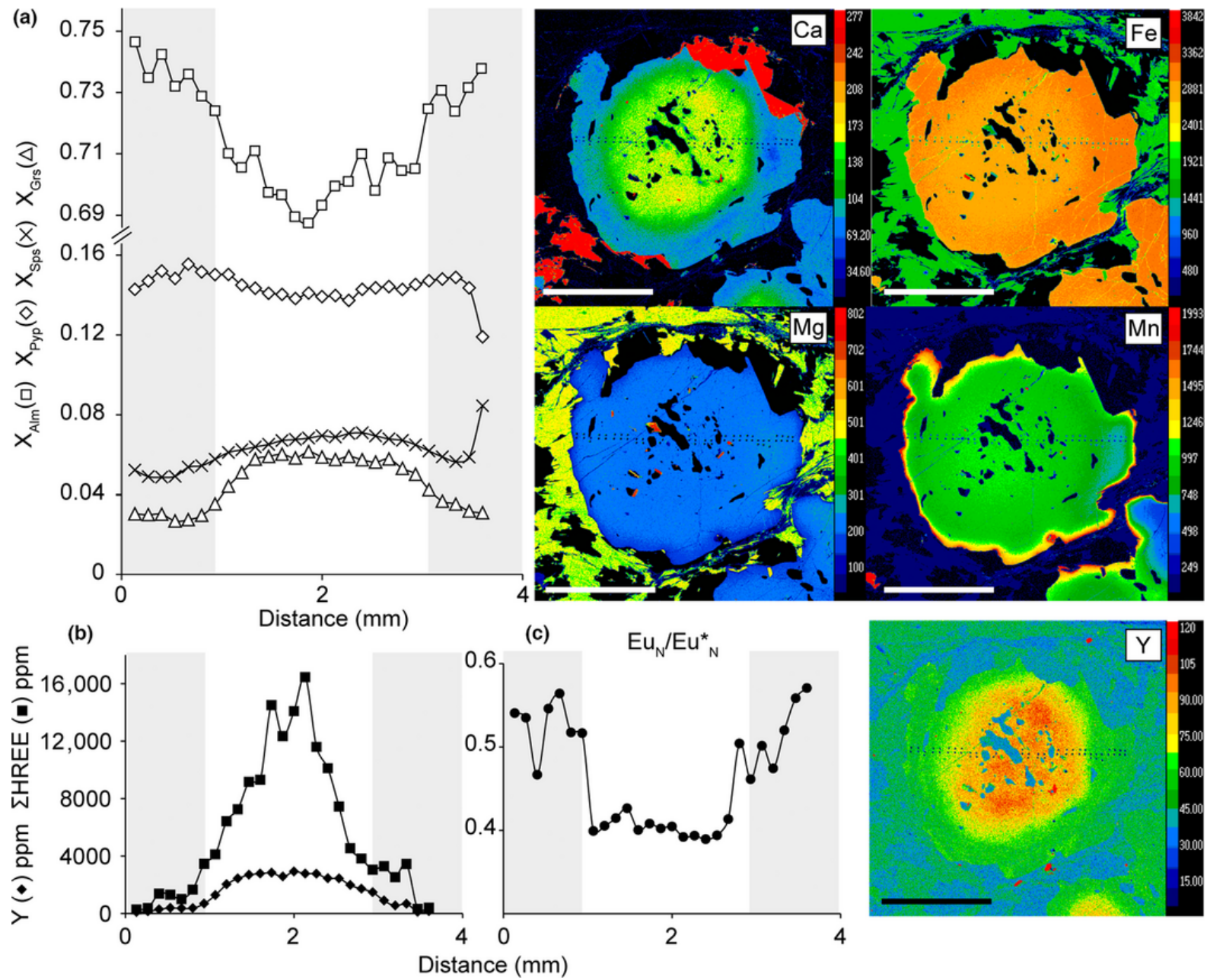

Fig. 4. Major and trace-element composition of garnet. X-ray compositional maps for $\mathrm{Ca}, \mathrm{Fe}, \mathrm{Mg}, \mathrm{Mn}$ and $Y$. Different colour scales (counts per second). (a) $X_{\mathrm{Alm}}, X_{\mathrm{Pyp}}, X_{\mathrm{Sps}}$ and $X_{\mathrm{Grs}}$ plotted against distance. (b) HREE and $Y$ show similar trends with enrichment in the core and depletion towards the rims. (c) $\mathrm{Eu}_{\mathrm{N}} / \mathrm{Eu}^{*}{ }_{\mathrm{N}}$ profile shows a decrease towards the $\operatorname{rim}\left(\mathrm{Eu}_{N} / \mathrm{Eu}^{*}{ }_{\mathrm{N}}=\mathrm{Eu_{N }} /\left(\mathrm{Sm}_{\mathrm{N}}{ }^{*} \mathrm{Gd}_{\mathrm{N}}\right)^{0.5} ; \mathrm{N}=\right.$ normalized to McDonough \& Sun ([9]). Scale bars in the maps $=2 \mathrm{~mm}$. 
(a) ZIRCON
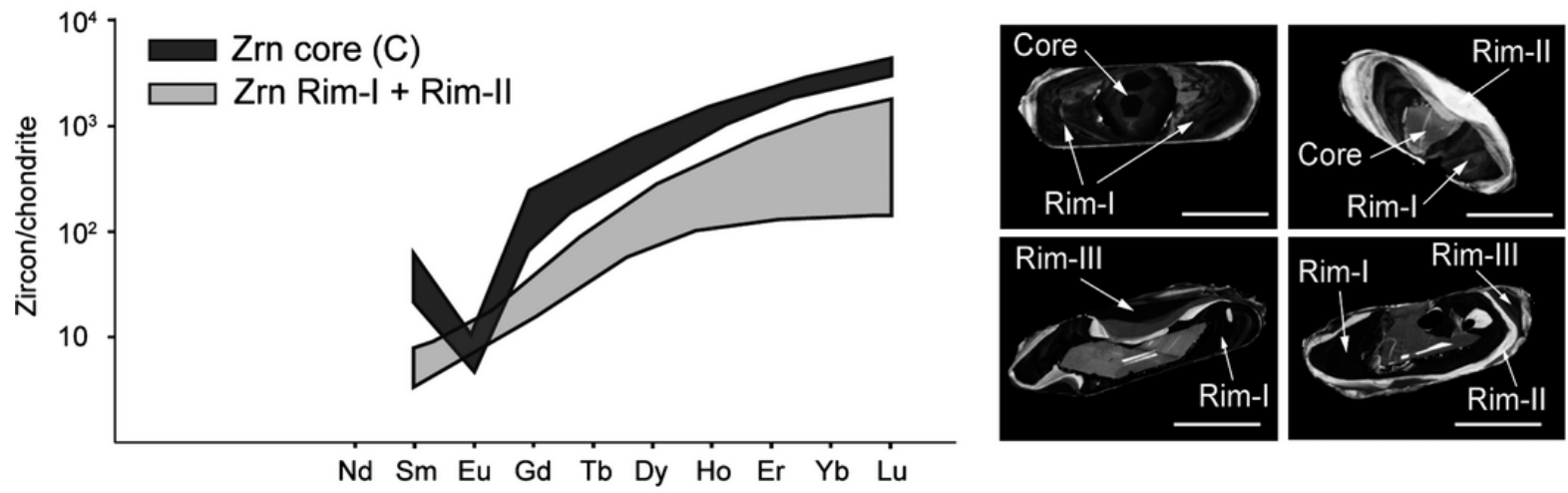

(b) MONAZITE
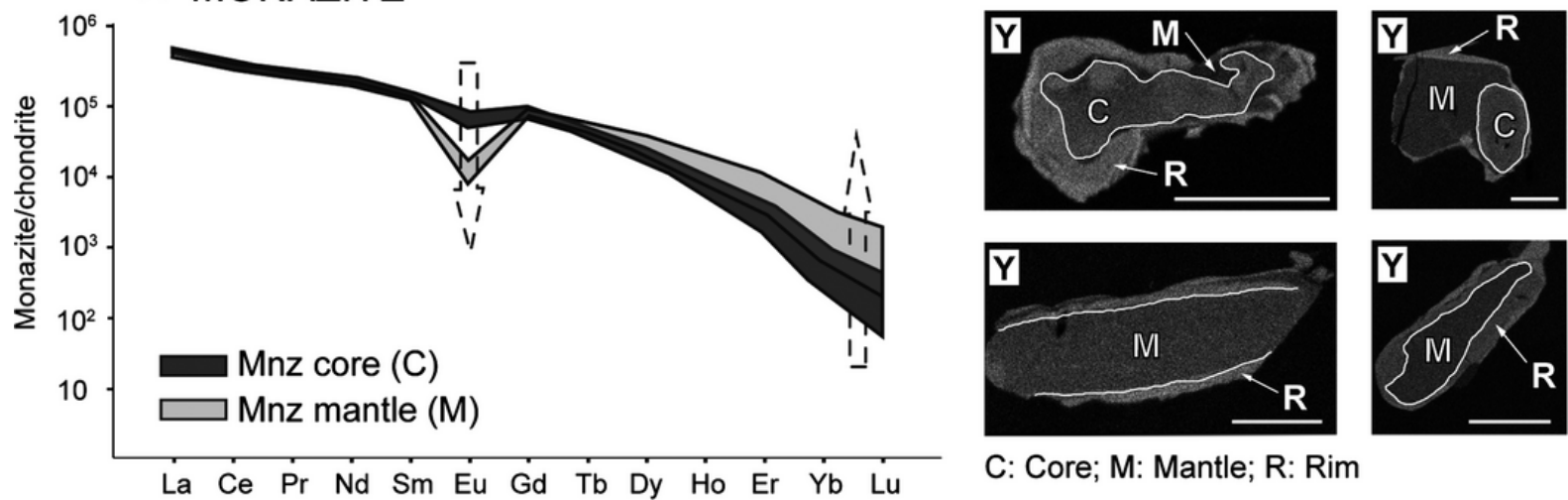

C: Core; M: Mantle; R: Rim

Fig. 5. (a) REE composition for zircon core and zircon rim-I + rim-II; CL images of zircon grains showing their internal growth structure. Scale bars are $50 \mu \mathrm{m}$. (b) REE composition of monazite core (C) and mantle (M); $R$ = rim. X-ray compositional maps of monazite grains showing three growth zones with different Yttrium compositions; Core and Rim are Y-enriched, Mantle is Y-depleted. Scale bars are $50 \mu \mathrm{m}$. All data are normalized to the chondritic values of McDonough \& Sun ([9]). 
(a) MnNKCFMASTH a( $\left.\mathrm{H}_{2} \mathrm{O}=1\right)$

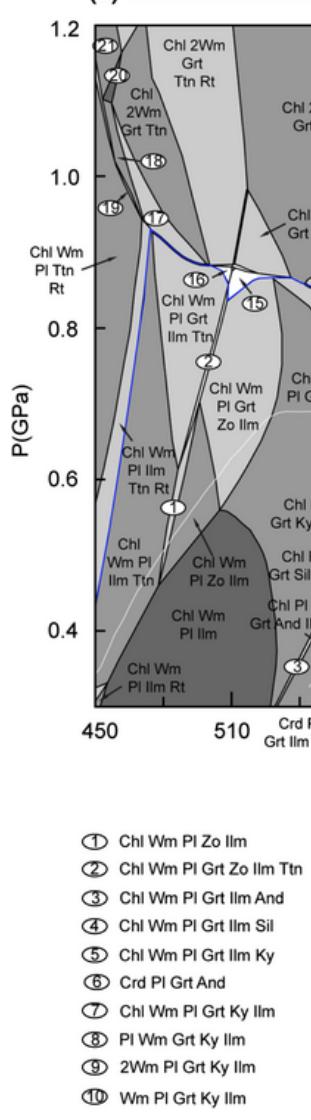

$+\mathrm{Bt}+\mathrm{Qz}$



(b) MnNKCFMASTH a( $\mathrm{H}_{2} \mathrm{O}=1$ )

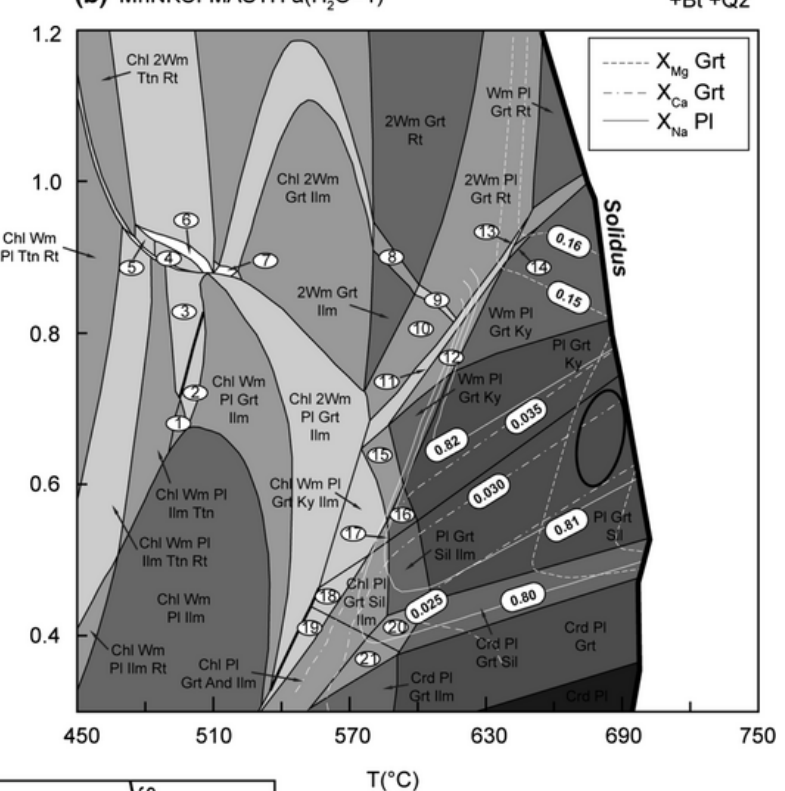

(11) $\mathrm{Chl} 2 \mathrm{Wm}$ PI Grt llm (12) $\mathrm{Chl} 2 \mathrm{Wm}$ Pl Grt Rt (13) $2 \mathrm{Wm}$ PI Grt Ky Rt (14) $\mathrm{Chl} 2 \mathrm{Wm}$ Grt llm Rt (15) Chl Wm PI Grt Zo llm Rt (16) Chl Wm Pl Grt llm Ttn Rt (1) $\mathrm{Chl} 2 \mathrm{Wm}$ Pl Grt Tt (18) Chl 2Wm Pl Ttn (19) $\mathrm{Chl} 2 \mathrm{Wm}$ PI IIm Ttn (20) Chl 2Wm Ttn (2D) $\mathrm{Chl} 2 \mathrm{Wm}$ Ttn Rt

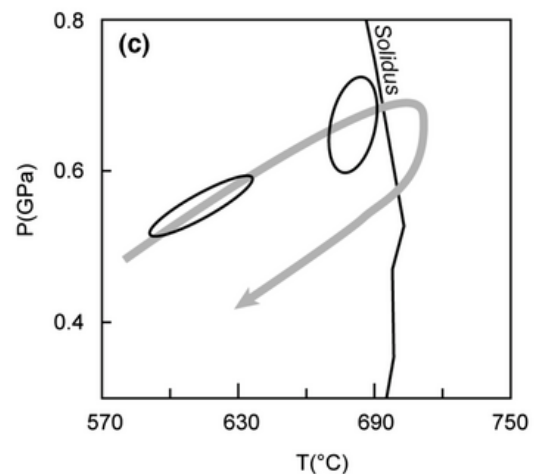

(11) $2 \mathrm{Wm}$ PI Grt Ky $1 \mathrm{~mm}$ (12) $2 \mathrm{Wm} P I G r t K y$ (13) $2 \mathrm{Wm}$ PI Grt Ky Rt (14) $\mathrm{Wm}$ PI Grt Ky $1 \mathrm{~m}$ (15) Wm PI Grt Ky llm (16) PI Grt Ky llm (17) ChI PI Grt Ky Ilm (18) Chl Wm Pl Grt Sil llm (19) Chl Wm PI Grt And IIm (2) Crd PI Grt Sil IIm (21) Crd PI Grt And IIm

Fig. 6. (a) $P-T$ pseudosection calculated in the MnNKCFMASTH system at $a\left(\mathrm{H}_{2} \mathrm{O}\right)=1$ using the unfractionated bulk composition (wt\%, $\mathrm{SiO}_{2}$ : $55.04 \mathrm{TiO}_{2}: 1.32 \mathrm{Al}_{2} \mathrm{O}_{3}$ : $18.13 \mathrm{FeO}: 12.8 \mathrm{MnO}: 0.18 \mathrm{MgO}$ : 4.80 CaO: $\left.0.80 \mathrm{Na}_{2} \mathrm{O}: 0.80 \mathrm{~K}_{2} \mathrm{O}: 5.31\right)$ and (b) the bulk composition for garnet rim growth (wt\%, $\mathrm{SiO}_{2}$ : 55.92 $\left.\mathrm{TiO}_{2}: 1.33 \mathrm{Al}_{2} \mathrm{O}_{3}: 17.84 \mathrm{FeO}: 13.30 \mathrm{MnO}: 0.17 \mathrm{MgO}: 4.40 \mathrm{CaO}: 0.43 \mathrm{Na}_{2} \mathrm{O}: 0.89 \mathrm{~K}_{2} \mathrm{O}: 5.35\right)$. In both pseudosections ( $a$ and $b$ ) the lightest shading represents fields that have a variance of 3 , with shading becoming darker with increasing variance, up to the darkest shading for the field with a variance of 8 . In (a) and (b), the compositional isopleths used to constrain the growth of garnet core and rim are: $\left[X_{M g} \mathrm{Grt}=\mathrm{Mg} /(\mathrm{Mg}+\mathrm{Fe}+\mathrm{Ca}+\mathrm{Mn}), X_{\mathrm{Ca}} \mathrm{Grt}=\mathrm{Ca} /(\mathrm{Ca}+\mathrm{Mg}+\mathrm{Fe}+\mathrm{Mn})\right.$, and $\left.X_{\mathrm{Na}, \mathrm{Pl}}=\mathrm{Na} /(\mathrm{Na}+\mathrm{Ca})\right]$. The two error ellipses reflect probe compositions of the garnet core (a) and garnet rim (b). The blue line in pseudosection (a) represents the ilmenite stability field. (c) Reconstructed $P-T$ path for the studied metapelite. 

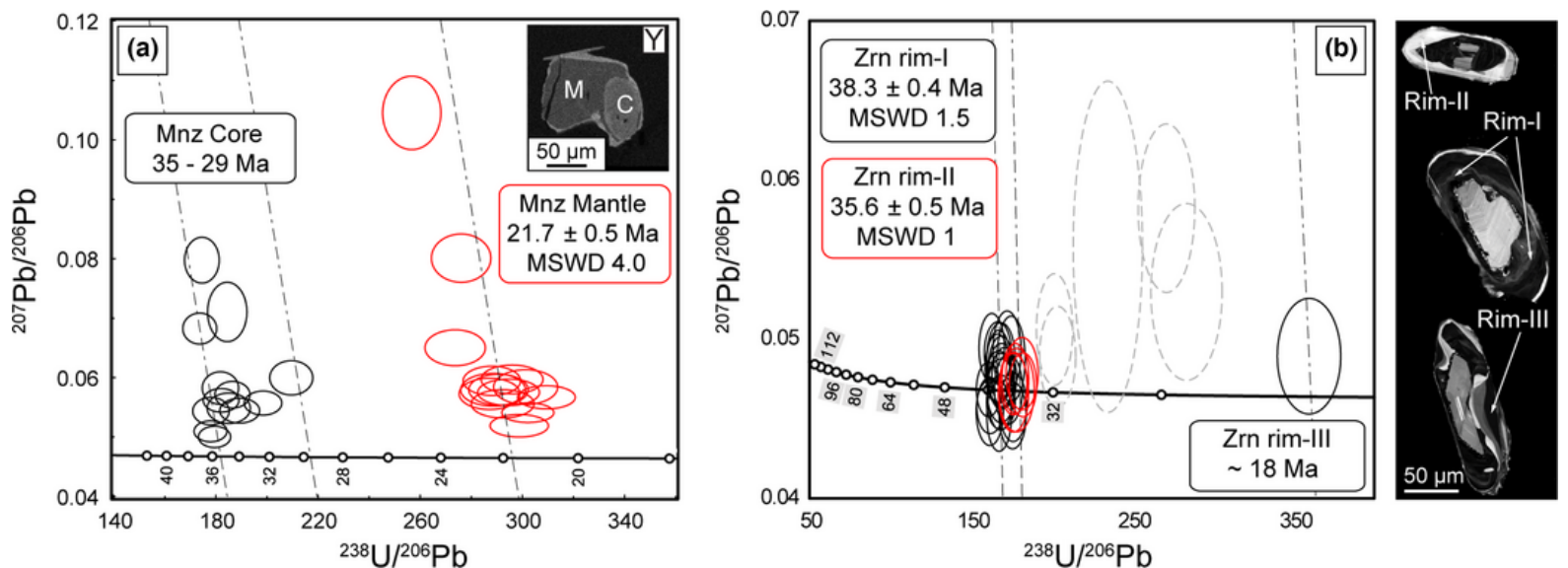

Fig. 7. (a) Tera-Wasserburg plot for monazite core and mantle. All data reported in Table 1. Monazite mantle age anchored to common $\mathrm{Pb}=0.83 \pm 0.02$. (b) Tera-Wasserburg plot for zircon metamorphic rims. Dotted ellipses excluded from calculations (mixed analysis between rim-II and rim-III). All ages are quoted at $2 \sigma$ and exclude systematic uncertainties.
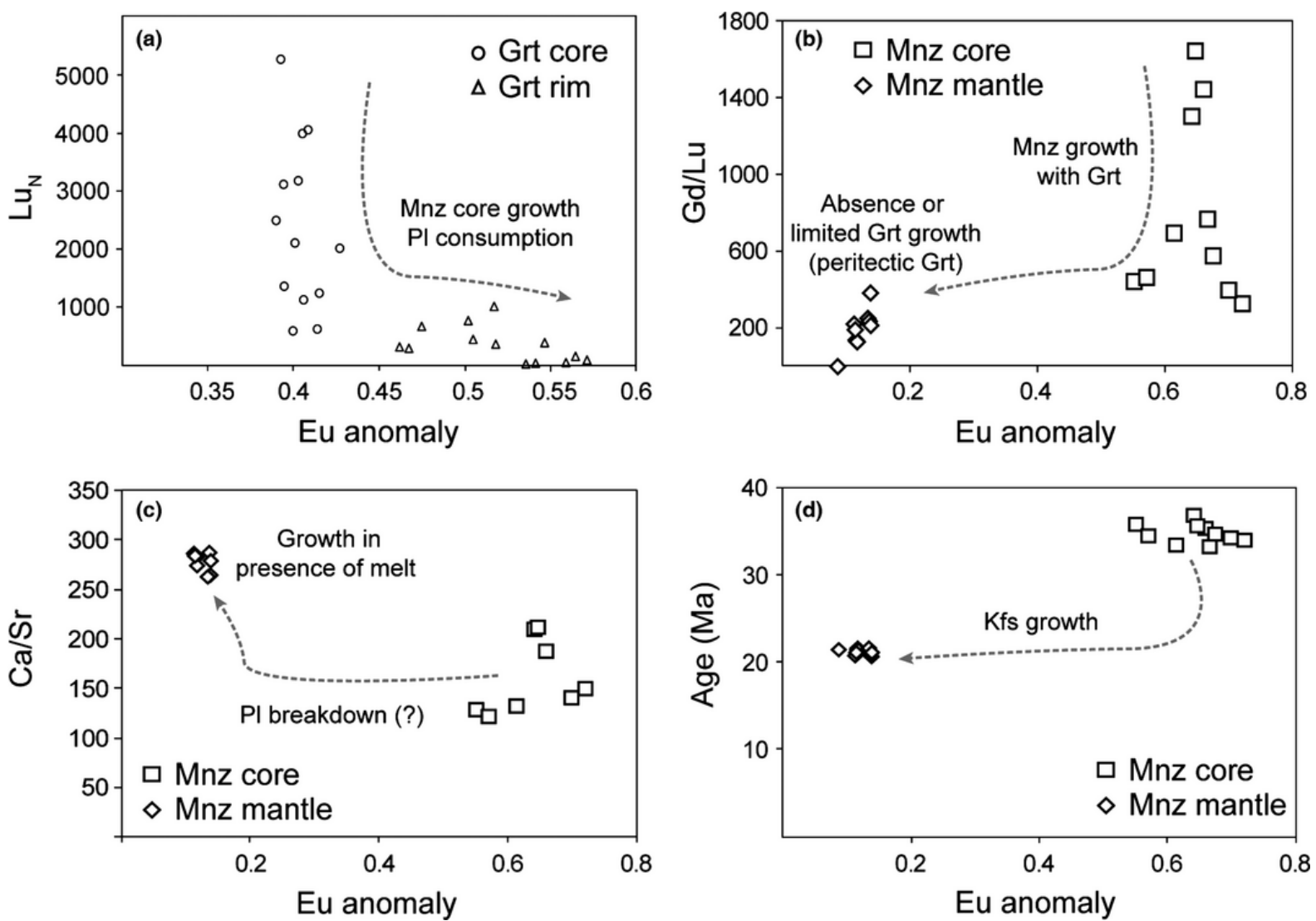

Fig. 8. 'Chemical fingerprints': trace-element composition for garnet and monazite. (a) Lu $u_{N} v$.

$\mathrm{Eu}_{\mathrm{N}} / \mathrm{Eu}_{\mathrm{N}}^{*}$ in garnet showing monazite core growth and plagioclase consumption during garnet core-torim growth. (b) Gd/Lu v. Eu $/ \mathrm{Eu}^{*}{ }_{N}$ in Mnz showing garnet influence on monazite growth in the subsolidus (for Mnz core) and supra-solidus (for Mnz mantle). (c) $\mathrm{Ca} / \mathrm{Sr} v$. $\mathrm{Eu}_{\mathrm{N}} / \mathrm{Eu}^{*}{ }_{\mathrm{N}}$ in monazite showing growth of monazite core in the presence of melt (enriched in Ca-An-component of plagioclase breakdown). (d) Age $v$. $E u_{N} / E u^{*}{ }_{N}$ in monazite showing K-feldspar growth in the supra-solidus (strong Eu anomaly in Mnz mantle) - see text for more details. 

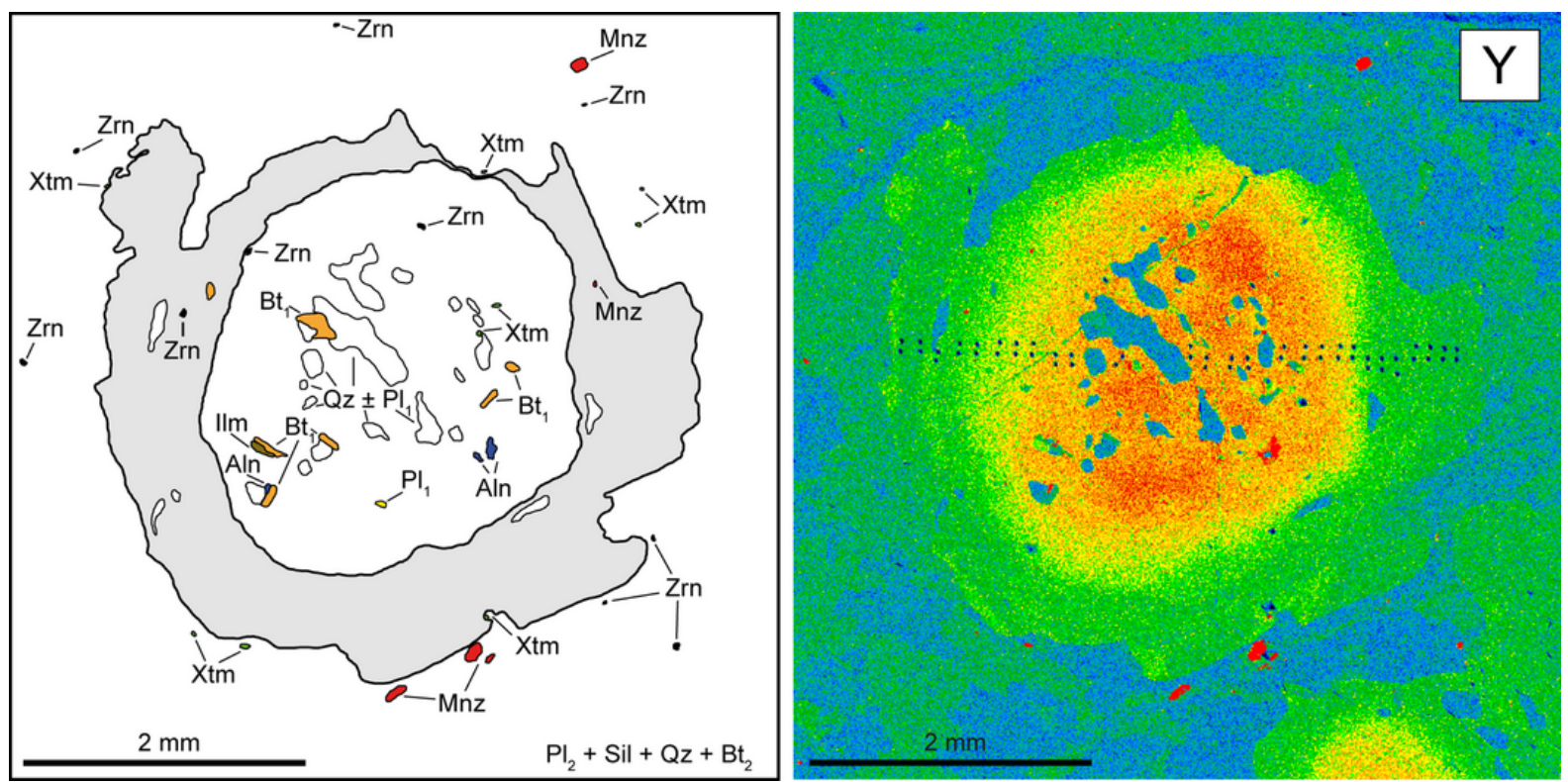

Fig. 9. Major and accessory phases included in garnet core and rim (Yttrium compositional map). Major: $\mathrm{Bt}_{1}, \mathrm{Pl}_{1}$ and $\mathrm{Qz}$ included in garnet core; rare quartz in garnet rim. Accessory: Allanite and ilmenite included in the high-Y garnet core; xenotime is preserved in garnet core and crystallized in the matrix around garnet rim. Monazite is found in garnet rim and in the matrix. Zircon is included in both garnet core and rim; abundant zircon in the rock matrix. 

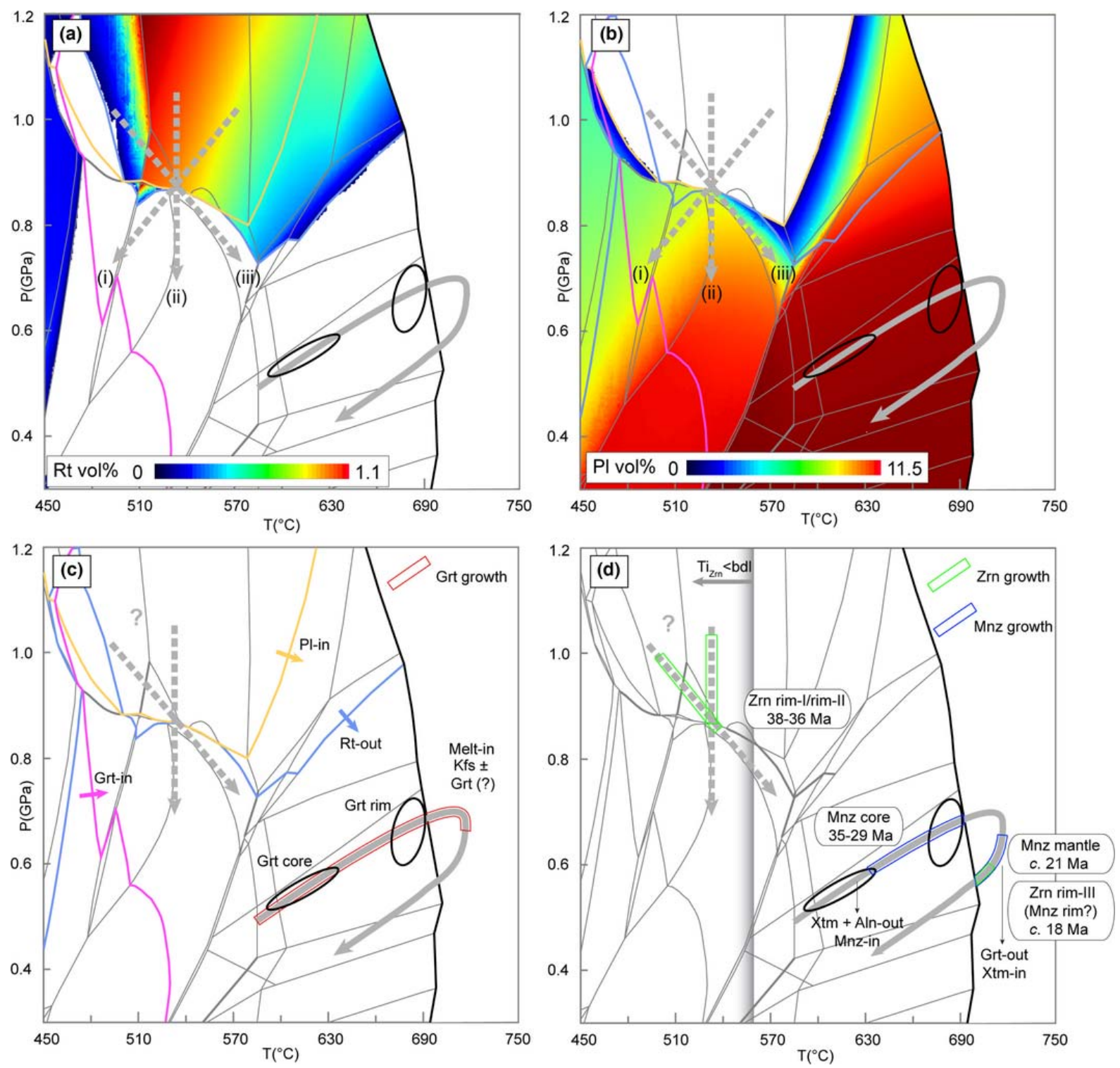

Fig. 10. Interpretative $P-T-t$ path for sample DRB1250. (a, b) Modal variation (vol.\%) of rutile and plagioclase calculated for the pseudosection in Fig. 1(garnet core composition). Ellipses correspond to garnet core and garnet rim growth. Dashed arrows: idealized $P-T$ trajectories involving (i) cooling during decompression, (ii) isothermal decompression and (iii) heating during decompression. (c) Major phases evolution along the reconstructed $P-T$ path; plagioclase, garnet and rutile assemblage field-boundaries have been highlighted on the $P-T$ diagram. (d) Accessory phases evolution and timing of crystallization along the same $P-T$ path. Thick black line: solidus, $\mathrm{Ti}_{\mathrm{z}_{\mathrm{m}}}=$ Ti-in-zircon, bdl $=$ below detection limit. 